\title{
Effects of $\mathrm{NO}_{x}$ and $\mathrm{SO}_{2}$ on the secondary organic aerosol formation from photooxidation of $\alpha$-pinene and limonene
}

\author{
Defeng Zhao ${ }^{1}$, Sebastian H. Schmitt ${ }^{1}$, Mingjin Wang ${ }^{1,2}$, Ismail-Hakki Acir ${ }^{1, a}$, Ralf Tillmann ${ }^{1}$, Zhaofeng Tan ${ }^{1,2}$, \\ Anna Novelli ${ }^{1}$, Hendrik Fuchs ${ }^{1}$, Iida Pullinen ${ }^{1, b}$, Robert Wegener ${ }^{1}$, Franz Rohrer ${ }^{1}$, Jürgen Wildt ${ }^{1}$, \\ Astrid Kiendler-Scharr ${ }^{1}$, Andreas Wahner ${ }^{1}$, and Thomas F. Mentel ${ }^{1}$ \\ ${ }^{1}$ Institute of Energy and Climate Research, IEK-8: Troposphere, Forschungszentrum Jülich, 52425 Jülich, Germany \\ ${ }^{2}$ College of Environmental Science and Engineering, Peking University, Beijing, 100871, China \\ ${ }^{a}$ now at: Institute of Nutrition and Food Sciences, University of Bonn, 53115 Bonn, Germany \\ b now at: Department of Applied Physics, University of Eastern Finland, 7021 Kuopio, Finland
}

Correspondence: Thomas F. Mentel (t.mentel@fz-juelich.de)

Received: 30 March 2017 - Discussion started: 4 April 2017

Revised: 27 November 2017 - Accepted: 29 December 2017 - Published: 5 February 2018

\begin{abstract}
Anthropogenic emissions such as $\mathrm{NO}_{x}$ and $\mathrm{SO}_{2}$ influence the biogenic secondary organic aerosol (SOA) formation, but detailed mechanisms and effects are still elusive. We studied the effects of $\mathrm{NO}_{x}$ and $\mathrm{SO}_{2}$ on the SOA formation from the photooxidation of $\alpha$-pinene and limonene at ambient relevant $\mathrm{NO}_{x}$ and $\mathrm{SO}_{2}$ concentrations $\left(\mathrm{NO}_{x}\right.$ : $<1$ to $20 \mathrm{ppb}, \mathrm{SO}_{2}$ : $<0.05$ to $15 \mathrm{ppb}$ ). In these experiments, monoterpene oxidation was dominated by $\mathrm{OH}$ oxidation. We found that $\mathrm{SO}_{2}$ induced nucleation and enhanced SOA mass formation. $\mathrm{NO}_{x}$ strongly suppressed not only new particle formation but also SOA mass yield. However, in the presence of $\mathrm{SO}_{2}$ which induced a high number concentration of particles after oxidation to $\mathrm{H}_{2} \mathrm{SO}_{4}$, the suppression of the mass yield of SOA by $\mathrm{NO}_{x}$ was completely or partly compensated for. This indicates that the suppression of SOA yield by $\mathrm{NO}_{x}$ was largely due to the suppressed new particle formation, leading to a lack of particle surface for the organics to condense on and thus a significant influence of vapor wall loss on SOA mass yield. By compensating for the suppressing effect on nucleation of $\mathrm{NO}_{x}, \mathrm{SO}_{2}$ also compensated for the suppressing effect on SOA yield. Aerosol mass spectrometer data show that increasing $\mathrm{NO}_{x}$ enhanced nitrate formation. The majority of the nitrate was organic nitrate (57$77 \%)$, even in low- $\mathrm{NO}_{x}$ conditions ( $\left.<\sim 1 \mathrm{ppb}\right)$. Organic nitrate contributed $7-26 \%$ of total organics assuming a molecular weight of $200 \mathrm{~g} \mathrm{~mol}^{-1}$. SOA from $\alpha$-pinene photooxidation at high $\mathrm{NO}_{x}$ had a generally lower hydrogen to carbon ratio $(\mathrm{H} / \mathrm{C})$, compared to low $\mathrm{NO}_{x}$. The $\mathrm{NO}_{x}$ dependence
\end{abstract}

of the chemical composition can be attributed to the $\mathrm{NO}_{x}$ dependence of the branching ratio of the $\mathrm{RO}_{2}$ loss reactions, leading to a lower fraction of organic hydroperoxides and higher fractions of organic nitrates at high $\mathrm{NO}_{x}$. While $\mathrm{NO}_{x}$ suppressed new particle formation and SOA mass formation, $\mathrm{SO}_{2}$ can compensate for such effects, and the combining effect of $\mathrm{SO}_{2}$ and $\mathrm{NO}_{x}$ may have an important influence on SOA formation affected by interactions of biogenic volatile organic compounds (VOCs) with anthropogenic emissions.

\section{Introduction}

Secondary organic aerosols (SOAs) have significant impacts on air quality, human health, and climate change (Hallquist et al., 2009; Kanakidou et al., 2005; Jimenez et al., 2009; Zhang et al., 2011). SOA mainly originates from biogenic volatile organic compounds (VOCs) emitted by terrestrial vegetation (Hallquist et al., 2009). Once emitted into the atmosphere, biogenic VOC can undergo reactions with atmospheric oxidants including $\mathrm{OH}, \mathrm{O}_{3}$, and $\mathrm{NO}_{3}$ and form SOA. When an air mass enriched in biogenic VOC is transported over an area with substantial anthropogenic emissions or vice versa, the reaction behavior of VOC and SOA formation can be altered due to the interactions of biogenic VOC with anthropogenic emissions such as $\mathrm{NO}_{x}, \mathrm{SO}_{2}$, anthropogenic aerosol, and anthropogenic VOC. A number of field studies have highlighted the role of the anthropogenic-biogenic interac- 
tions in SOA formation (de Gouw et al., 2005; Goldstein et al., 2009; Hoyle et al., 2011; Worton et al., 2011; Glasius et al., 2011; Xu et al., 2015a; Shilling et al., 2013), which can induce an "anthropogenic enhancement" effect on SOA formation.

Among biogenic VOCs, monoterpenes are important contributors to biogenic SOA due to their high emission rates, high reactivity, and relatively high SOA yield compared to isoprene (Guenther et al., 1995, 2012; Chung and Seinfeld, 2002; Pandis et al., 1991; Griffin et al., 1999; Hoffmann et al., 1997; Zhao et al., 2015b; Carlton et al., 2009). The anthropogenic modulation of the SOA formation from monoterpenes can have important impacts on the regional and global biogenic SOA budget (Spracklen et al., 2011). The influence of various anthropogenic pollutants on SOA formation of monoterpenes has been investigated by a number of laboratory studies (Sarrafzadeh et al., 2016; Zhao et al., 2016; Flores et al., 2014; Emanuelsson et al., 2013; Eddingsaas et al., 2012a; Offenberg et al., 2009; Kleindienst et al., 2006; Presto et al., 2005; $\mathrm{Ng}$ et al., 2007; Zhang et al., 1992; Pandis et al., 1991; Draper et al., 2015; Han et al., 2016). In particular, $\mathrm{NO}_{x}$ and $\mathrm{SO}_{2}$ have been shown to affect SOA formation from monoterpenes.

$\mathrm{NO}_{x}$ changes the fate of the $\mathrm{RO}_{2}$ radical formed in VOC oxidation and therefore can change reaction product distribution and aerosol formation. At low $\mathrm{NO}_{x}, \mathrm{RO}_{2}$ mainly react with $\mathrm{HO}_{2}$, forming organic hydroperoxides. At high $\mathrm{NO}_{x}$, $\mathrm{RO}_{2}$ mainly react with $\mathrm{NO}$, forming organic nitrate (Hallquist et al., 2009; Ziemann and Atkinson, 2012; FinlaysonPitts and Pitts Jr., 1999). Some studies found that the SOA yield from $\alpha$-pinene is higher at lower $\mathrm{NO}_{x}$ concentration for ozonolysis (Presto et al., 2005) and photooxidation ( $\mathrm{Ng}$ et al., 2007; Eddingsaas et al., 2012a; Han et al., 2016; Stirnweis et al., 2017). The decrease in SOA yield with increasing $\mathrm{NO}_{x}$ was proposed to be due to the formation of more volatile products like organic nitrate under high- $\mathrm{NO}_{x}$ conditions (Presto et al., 2005). In contrast, a recent study found that the suppressing effect of $\mathrm{NO}_{x}$ is in large part attributed to the effect of $\mathrm{NO}_{x}$ on $\mathrm{OH}$ concentration for the SOA from $\beta$ pinene oxidation, and, after eliminating the effect of $\mathrm{NO}_{x}$ on OH concentration, SOA yield only varies by $20-30 \%$ (Sarrafzadeh et al., 2016). In addition to the effect of $\mathrm{NO}_{x}$ on SOA yield, $\mathrm{NO}_{x}$ has been found to suppress the new particle formation from VOC directly emitted by Mediterranean trees (mainly monoterpenes; Wildt et al., 2014) and $\beta$-pinene (Sarrafzadeh et al., 2016), thereby reducing the condensational sink present during high- $\mathrm{NO}_{x}$ experiments.

Regarding the effect of $\mathrm{SO}_{2}$, the SOA yield of $\alpha$-pinene photooxidation was found to increase with $\mathrm{SO}_{2}$ concentration at high $\mathrm{NO}_{x}$ concentrations $\left(\mathrm{SO}_{2}: 0-252, \mathrm{NO}_{x}: 242\right.$ 543, $\alpha$-pinene: $178-255 \mathrm{ppb}$; Kleindienst et al., 2006) and the increase is attributed to the formation of $\mathrm{H}_{2} \mathrm{SO}_{4}$ acidic aerosol. Acidity of seed aerosol was also found to enhance particle yield of $\alpha$-pinene at high $\mathrm{NO}_{x}$ (Offenberg et al., 2009: $\mathrm{NO}_{x}$ 100-120, $\alpha$-pinene 69-160; Han et al., 2016: initial NO $\sim 70 \mathrm{ppb}, \alpha$-pinene 14-18 ppb). In contrast, Eddingsaas et al. (2012a) found that particle yield increases with aerosol acidity only in high-NO condition $\left(\mathrm{NO}_{x}: 800\right.$, $\alpha$-pinene: $20-52 \mathrm{ppb}$ ) but is independent of the presence of seed aerosol or aerosol acidity in both high- $\mathrm{NO}_{2}$ condition $\left(\mathrm{NO}_{x} 800 \mathrm{ppb}\right)$ and low $\mathrm{NO}_{x}\left(\mathrm{NO}_{x}\right.$ lower than the detection limit of the $\mathrm{NO}_{x}$ analyzer). Similarly, at low $\mathrm{NO}_{x}$ (initial $\mathrm{NO}<0.3, \alpha$-pinene $\sim 20 \mathrm{ppb}$ ), Han et al. (2016) found that the acidity of seed has no significant effect on SOA yield from $\alpha$-pinene photooxidation. In addition, $\mathrm{SO}_{2}$ was found to influence the gas-phase oxidation products from $\alpha$-pinene and $\beta$-pinene photooxidation, which is possibly due to the change in the $\mathrm{OH} / \mathrm{HO}_{2}$ ratio caused by $\mathrm{SO}_{2}$ oxidation or $\mathrm{SO}_{3}$ directly reacting with organic molecules (Friedman et al., 2016).

While these studies have provided valuable insights into the effects of $\mathrm{NO}_{x}$ and $\mathrm{SO}_{2}$ on $\mathrm{SOA}$ formation, a number of questions still remain elusive. For example, many studies used very high $\mathrm{NO}_{x}$ and $\mathrm{SO}_{2}$ concentrations (up to several hundreds of ppb). High $\mathrm{NO}_{x}$ can make the $\mathrm{RO}_{2}$ radical fate dominated by one single pathway (i.e., $\mathrm{RO}_{2}+\mathrm{NO}$ or $\mathrm{RO}_{2}+\mathrm{NO}_{2}$ ), which allows one to investigate the SOA yields and composition under the exclusively high- $\mathrm{NO}$ or high- $\mathrm{NO}_{2}$ conditions. Yet, the effects of $\mathrm{NO}_{x}$ and $\mathrm{SO}_{2}$ at concentration ranges for ambient anthropogenic-biogenic interactions (sub-ppb to several tens of ppb for $\mathrm{NO}_{2}$ and $\mathrm{SO}_{2}$ ) have seldom been directly addressed. Moreover, many previous studies on the SOA formation from monoterpene oxidation focus on ozonolysis or do not distinguish $\mathrm{OH}$ oxidation and ozonolysis in photooxidation, and only a few studies on $\mathrm{OH}$ oxidation have been conducted (Eddingsaas et al., 2012a; Zhao et al., 2015b; McVay et al., 2016; Sarrafzadeh et al., 2016; Henry et al., 2012; Ng et al., 2007). More importantly, studies that investigated the combined effects of $\mathrm{NO}_{x}$ and $\mathrm{SO}_{2}$ are scarce, although they are often co-emitted from anthropogenic sources. According to previous studies, $\mathrm{NO}_{x}$ can have a suppressing effect on $\mathrm{SOA}$ formation while $\mathrm{SO}_{2}$ can have an enhancing effect. $\mathrm{NO}_{x}$ and $\mathrm{SO}_{2}$ might have counteracting or synergistic effects on SOA formation in the ambient atmosphere.

In this study, we investigated the effects of $\mathrm{NO}_{x}, \mathrm{SO}_{2}$, and their combining effects on SOA formation from the photooxidation of $\alpha$-pinene and limonene. $\alpha$-Pinene and limonene are two important monoterpenes with high emission rates among monoterpenes (Guenther et al., 2012). OH oxidation dominated over ozonolysis in the monoterpene oxidation in this study as determined by measured $\mathrm{OH}$ and $\mathrm{O}_{3}$ concentrations. The relative contributions of $\mathrm{RO}_{2}$ loss reactions at low $\mathrm{NO}_{x}$ and high $\mathrm{NO}_{x}$ were quantified using measured $\mathrm{HO}_{2}$, $\mathrm{RO}_{2}$, and NO concentrations. The effects on new particle formation, SOA yield, and aerosol chemical composition were examined. We used ambient relevant $\mathrm{NO}_{x}$ and $\mathrm{SO}_{2}$ concentrations so that the results can shed lights on the mechanisms of interactions of biogenic VOC with anthropogenic emissions in the real atmosphere. 


\section{Experimental}

\subsection{Experimental setup and instrumentation}

The experiments were performed in the SAPHIR chamber (simulation of atmospheric photochemistry in a large reaction chamber) at Forschungszentrum Jülich, Germany. The details of the chamber have been described before (Rohrer et al., 2005; Zhao et al., 2015a, b). Briefly, it is a $270 \mathrm{~m}^{3}$ Teflon chamber using natural sunlight for illumination. It is equipped with a louvre system to switch between light and dark conditions. The physical parameters for chamber running such as temperature and relative humidity $(\mathrm{RH})$ were recorded. The solar irradiation was characterized and the photolysis frequency was derived (Bohn et al., 2005; Bohn and Zilken, 2005).

Gas- and particle-phase species were characterized using various instruments. $\mathrm{OH}, \mathrm{HO}_{2}$, and $\mathrm{RO}_{2}$ concentrations were measured using a laser-induced fluorescence system with details described by Fuchs et al. (2012). OH was formed via HONO photolysis, which was produced from a photolytic process on the Teflon chamber wall (Rohrer et al., 2005). From $\mathrm{OH}$ concentration, $\mathrm{OH}$ dose, the integral of $\mathrm{OH}$ concentration over time, was calculated in order to better compare experiments with different $\mathrm{OH}$ levels. For example, experiments at high $\mathrm{NO}_{x}$ in this study generally had higher $\mathrm{OH}$ concentrations due to the faster $\mathrm{OH}$ production by recycling of $\mathrm{HO}_{2}$ • and $\mathrm{RO}_{2}$ • to $\mathrm{OH}$. The VOCs were characterized using a proton-transfer-reaction time-of-flight mass spectrometer (PTR-ToF-MS) and gas chromatography mass spectrometer (GC-MS). $\mathrm{NO}_{x}, \mathrm{O}_{3}$, and $\mathrm{SO}_{2}$ concentrations were characterized using a $\mathrm{NO}_{x}$ analyzer (Eco Physics TR480), an $\mathrm{O}_{3}$ analyzer (Ansyco, model $\mathrm{O} 341 \mathrm{M}$ ), and an $\mathrm{SO}_{2}$ analyzer (Thermo Systems 43i), respectively. $\mathrm{O}_{3}$ was formed in photochemical reactions since $\mathrm{NO}_{x}$, even in trace amount $(<\sim 1 \mathrm{ppbV})$, was present in this study. More details of the instrumentation are described before (Zhao et al., 2015b).

The number and size distribution of particles were measured using a condensation particle counter (CPC; TSI, model 3786) and a scanning mobility particle sizer (SMPS; TSI, DMA 3081/CPC 3785). From particle number measurement, the nucleation rate $\left(J_{2.5}\right)$ was derived from the number concentration of particles larger than $2.5 \mathrm{~nm}$ as measured by CPC. Particle chemical composition was measured using a high-resolution time-of-flight aerosol mass spectrometer (HR-ToF-AMS, Aerodyne Research Inc.). From the AMS data, the oxygen to carbon ratio $(\mathrm{O} / \mathrm{C})$, hydrogen to carbon ratio $(\mathrm{H} / \mathrm{C})$, and nitrogen to carbon ratio $(\mathrm{N} / \mathrm{C})$ were derived using a method derived in the literature (Aiken et al., 2007, 2008). An update procedure to determine the elemental composition is reported by Canagaratna et al. (2015), showing the $\mathrm{O} / \mathrm{C}$ and $\mathrm{H} / \mathrm{C}$ derived from the method of Aiken et al. (2008) may be underestimated. The $\mathrm{H} / \mathrm{C}$ and $\mathrm{O} / \mathrm{C}$ were also derived using the newer approach by Canagaratna et al. (2015) and compared with the data derived from the
Aiken et al. (2007) method. The H / C values derived using the Canagaratna et al. (2015) method strongly correlated with the values derived using the Aiken et al. (2007) method (Fig. S1 in the Supplement) and just increased by $27 \%$ as suggested by Canagaratna et al. (2015). Similar results were found for $\mathrm{O} / \mathrm{C}$ and there was just a difference of $11 \%$ in $\mathrm{O} / \mathrm{C}$. Since only the relative difference in elemental composition of SOA is studied here, only the data derived using the Aiken et al. (2007) method are shown as the conclusion was not affected by the methods chosen. The fractional contributions of organics in the signals at $m / z=44$ and $m / z=43$ to total organics ( $f_{44}$ and $f_{43}$, respectively) were also derived.

SOA yields were calculated as the ratio of organic aerosol mass formed to the amount of VOC reacted. The mass concentration of organic aerosol was derived using the total aerosol volume concentration measured by SMPS multiplied by the volume fraction of organics with a density of $1 \mathrm{~g} \mathrm{~cm}^{-3}$ to better compare with previous literature. In the experiments with added $\mathrm{SO}_{2}$, sulfuric acid was formed upon photooxidation and partly neutralized by background ammonia, which was introduced into the chamber mainly due to humidification. The volume fraction of organics was derived based on volume additivity using the mass of organics and ammonium sulfate and ammonium bisulfate from AMS and their respective density $\left(1.32 \mathrm{~g} \mathrm{~cm}^{-3}\right.$ for organic aerosol from one of our previous studies (Flores et al., 2014) and the literature $(\mathrm{Ng}$ et al., 2007) and $\sim 1.77 \mathrm{~g} \mathrm{~cm}^{-3}$ for ammonium sulfate and ammonium bisulfate). According to the calculations based on the E-AIM model (Clegg et al., 1998; Wexler and Clegg, 2002; http://www.aim.env.uea.ac.uk/aim/aim.php), there was no aqueous phase formed at the relative humidity in the experiments of this study. The average $\mathrm{RH}$ for the period of monoterpene photooxidation was 28-34\% except for one experiment with average $\mathrm{RH}$ of $42 \% \mathrm{RH}$. The organic aerosol concentration was corrected for the particle wall loss and dilution loss using the method described in Zhao et al. (2015b).

\subsection{Experimental procedure}

The SOA formation from $\alpha$-pinene and limonene photooxidation was investigated at different $\mathrm{NO}_{x}$ and $\mathrm{SO}_{2}$ levels. Four types of experiments were done: with neither $\mathrm{NO}_{x}$ nor $\mathrm{SO}_{2}$ added (referred to as "low $\mathrm{NO}_{x}$, low $\mathrm{SO}_{2}$ "), with only $\mathrm{NO}_{x}$ added $\left(\sim 20 \mathrm{ppb} \mathrm{NO}\right.$, referred to as "high $\mathrm{NO}_{x}$, low $\mathrm{SO}_{2}$ "), with only $\mathrm{SO}_{2}$ added ( $\sim 15 \mathrm{ppb}$, referred to as "low $\mathrm{NO}_{x}$, high $\mathrm{SO}_{2}$ "), and with both $\mathrm{NO}_{x}$ and $\mathrm{SO}_{2}$ added $\left(\sim 20 \mathrm{ppb} \mathrm{NO}\right.$ and $\sim 15 \mathrm{ppb} \mathrm{\textrm {SO } _ { 2 }}$, referred to as "high $\mathrm{NO}_{x}$, high $\mathrm{SO}_{2}$ "). For low- $\mathrm{NO}_{x}$ conditions, background $\mathrm{NO}$ concentrations were around $0.05-0.2 \mathrm{ppb}$, and background NO was mainly from a photolytic process of Teflon as chamber wall. (Rohrer et al., 2005). For low- $\mathrm{SO}_{2}$ conditions, background $\mathrm{SO}_{2}$ concentrations were below the detection limit of the $\mathrm{SO}_{2}$ analyzer $(0.05 \mathrm{ppb})$. In some experiments, a lower level of $\mathrm{SO}_{2}$ (2 ppb, referred to as "moderate $\mathrm{SO}_{2}$ ") was used 
Table 1. Overview of the experiments in this study.

\begin{tabular}{lllrr}
\hline Precursor & $\mathrm{SO}_{2}$ & $\mathrm{NO}_{x}$ & $\mathrm{NO}(\mathrm{ppb})$ & $\mathrm{SO}_{2}(\mathrm{ppb})$ \\
\hline$\alpha$-pinene & Low $\mathrm{SO}_{2}$ & Low NO $_{x}$ & $0.05-0.2$ & $<0.05$ \\
$(\sim 20 \mathrm{ppb})$ & & $\mathrm{High} \mathrm{NO}_{x}$ & $\sim 20$ & $<0.05$ \\
& $\mathrm{High} \mathrm{SO}_{2}$ & Low NO $_{x}$ & $0.05-0.2$ & $\sim 15$ \\
& & $\mathrm{High} \mathrm{NO}_{x}$ & $\sim 20$ & $\sim 15$ \\
Limonene & Low $\mathrm{SO}_{2}$ & Low NO $_{x}$ & $0.05-0.2$ & $<0.05$ \\
$(\sim 7 \mathrm{ppb})$ & & $\mathrm{High} \mathrm{NO}_{x}$ & $\sim 20$ & $<0.05$ \\
& $\mathrm{High} \mathrm{SO}_{2}$ & Low NO $_{x}$ & $0.05-0.2$ & $\sim 15$ \\
& & $\mathrm{High} \mathrm{NO}_{x}$ & $\sim 20$ & $\sim 15$ \\
& Moderate $\mathrm{SO}_{2}$ & High NO $_{x}$ & $\sim 20$ & $\sim 2$ \\
\hline
\end{tabular}

to test the effect of $\mathrm{SO}_{2}$ concentration. An overview of the experiments is shown in Table 1.

In a typical experiment, the chamber was humidified to $\sim 75 \% \mathrm{RH}$ first, and then VOC and NO, if applicable, were added to the chamber. Then the roof was opened to start photooxidation. In the experiments with $\mathrm{SO}_{2}, \mathrm{SO}_{2}$ was added and the roof was opened to initialize nucleation first and then VOC was added. The particle number concentration caused by $\mathrm{SO}_{2}$ oxidation typically reached several tens of thousands $\mathrm{cm}^{-3}$ (see Fig. 2 high-SO $\mathrm{SO}_{2}$ cases) and, after VOC addition, no further nucleation occurred. Adding $\mathrm{SO}_{2}$ first and initializing nucleation by $\mathrm{SO}_{2}$ photooxidation ensured that enough nucleating particles were present when VOC oxidation started. $\mathrm{SO}_{2}$ concentration decayed slowly in the experiments with $\mathrm{SO}_{2}$ added and most of the $\mathrm{SO}_{2}$ was still left (typically around $8 \mathrm{ppb}$ from initial $15 \mathrm{ppb}$ ) at the end of an experiment due to its low reactivity with $\mathrm{OH}$. Typical $\mathrm{SO}_{2}$ time series in high-SO $\mathrm{SO}_{2}$ experiments are shown in Fig. S2. The detailed conditions of the experiments are shown in Table S1 in the Supplement. The experiments of $\alpha$-pinene and limonene photooxidation were designed to keep the initial $\mathrm{OH}$ reactivity and thus $\mathrm{OH}$ loss rate constant so that the $\mathrm{OH}$ concentrations of these experiments were more comparable. Therefore, the concentration of limonene was around onethird of the concentration of $\alpha$-pinene due to the higher $\mathrm{OH}$ reactivity of limonene.

\subsection{Wall loss of organic vapors}

The loss of organic vapors on chamber walls can influence SOA yield (Kroll et al., 2007; Zhang et al., 2014; Ehn et al., 2014; Sarrafzadeh et al., 2016; McVay et al., 2016; Nah et al., 2016; Matsunaga and Ziemann, 2010; Ye et al., 2016; Loza et al., 2010). The wall loss rate of organic vapors in our chamber was estimated by following the decay of organic vapor concentrations after photooxidation was stopped in the experiments with low particle surface area $\left(\sim 5 \times 10^{-8} \mathrm{~cm}^{2} \mathrm{~cm}^{-3}\right)$ and thus low condensational sink on particles. Such method is similar to the method used in previous studies (Ehn et al., 2014; Sarrafzadeh et al., 2016; Krechmer et al., 2016; Zhang et al., 2015). A high-resolution time-of-flight chemical ionization mass spectrometer (HRToF-CIMS, Aerodyne Research Inc.) with nitrate ion source $\left({ }^{15} \mathrm{NO}_{3}^{-}\right)$was used to measure semi/low-volatility organic vapors. The details of the instrument were described in our previous studies (Ehn et al., 2014; Sarrafzadeh et al., 2016). The decay of vapors started from the time when the roof of the chamber was closed. The data were acquired at a time resolution of $4 \mathrm{~s}$. A typical decay of low-volatility organics is shown in Fig. S3 and the first-order wall loss rate was determined to be around $6 \times 10^{-4} \mathrm{~s}^{-1}$.

The SOA yield was not directly corrected for the vapor wall loss, but the influence of vapor wall loss on SOA yield was estimated using the method in the study of Sarrafzadeh et al. (2016) and the details of the method are described therein. Briefly, particle surface and chamber walls competed for the vapor loss (condensation) and the condensation on particles led to particle growth. The fraction of organic vapor loss to particles in the sum of the vapor loss to chamber walls plus the vapor loss to particles $\left(F_{\mathrm{p}}\right)$ was calculated. The vapor loss to chamber walls was derived using the wall loss rate. The vapor loss to particles was derived using particle surface area concentration, molecular velocity, and an accommodation coefficient $\alpha_{\mathrm{p}}$ (Sarrafzadeh et al., 2016). 1/ $F_{\mathrm{p}}\left(f_{\text {corr }}\right)$ provides the correction factor to obtain the "real" SOA yield. $f_{\text {corr }}$ is a function of the particle surface area concentration and accommodation coefficient as shown in Fig. S4. Here a range of $0.1-1$ for $\alpha_{\mathrm{p}}$ was used, which is generally in line with the ranges of $\alpha_{\mathrm{p}}$ found by Nah et al. (2016) by fitting a vapor-particle dynamic model to experimental data. At a given $\alpha_{\mathrm{p}}$, the higher particle surface area, the lower $f_{\text {corr }}$, and the lower the influence of vapor wall loss are because most vapors condense on particle surface and vice versa. At a given particle surface area, $f_{\text {corr }}$ decreases with $\alpha_{\mathrm{p}}$ because at higher $\alpha_{\mathrm{p}}$ a larger fraction of vapors condenses on particles. An average molecular weight of $200 \mathrm{~g} \mathrm{~mol}^{-1}$ was used to estimate the influence of vapor wall loss. For the aerosol surface area range in most of the experiments in this study (larger than $3 \times 10^{-6} \mathrm{~cm}^{2} \mathrm{~cm}^{-3}$ ), $f_{\text {corr }}$ is less than 1.4 (Fig. S4) and thus the influence of vapor wall loss on SOA yield was relatively small $(<\sim 40 \%)$. Yet, for the experiments at high $\mathrm{NO}_{x}$ and low $\mathrm{SO}_{2}$ for $\alpha$-pinene and limonene, 
the influence of vapor wall loss on SOA can be high due to the low particle surface area, especially at lower $\alpha_{\mathrm{p}}$. We did not directly correct SOA yield for vapor wall loss because the correction factor $\left(f_{\text {corr }}\right)$ curve in the low surface area range is very steep and has very large uncertainties (Fig. S4). In addition, $\alpha_{\mathrm{p}}$ also has uncertainties and may depend on the identity of each condensable compound.

\section{Results and discussion}

\subsection{Chemical scheme: VOC oxidation pathway and $\mathrm{RO}_{2}$ fate}

In the photooxidation of $\mathrm{VOC}, \mathrm{OH}$ and $\mathrm{O}_{3}$ often coexist and both contribute to $\mathrm{VOC}$ oxidation because $\mathrm{O}_{3}$ formation in chamber studies is often unavoidable during photochemical reactions of VOC even in the presence of trace amount of $\mathrm{NO}_{x}$. In order to study the mechanism of SOA formation, it is helpful to isolate one oxidation pathway from the other. In this study, the reaction rates of $\mathrm{OH}$ and ozone with VOC are quantified using measured $\mathrm{OH}$ and $\mathrm{O}_{3}$ concentrations multiplied by rate constants (time series of VOC, $\mathrm{OH}$, and $\mathrm{O}_{3}$ are shown in Fig. S5). Typical $\mathrm{OH}$ and $\mathrm{O}_{3}$ concentrations in an experiment were around (1-15) $\times 10^{6}$ molecules $\mathrm{cm}^{-3}$ and $0-50 \mathrm{ppb}$, respectively, depending on the VOC and $\mathrm{NO}_{x}$ concentrations added. For all the experiment in this study, the VOC loss was dominated by $\mathrm{OH}$ oxidation over ozonolysis (see Fig. S6 as an example). The relative importance of the reaction of $\mathrm{OH}$ and $\mathrm{O}_{3}$ with monoterpenes was similar in the low- $\mathrm{NO}_{x}$ and high- $\mathrm{NO}_{x}$ experiments. At high $\mathrm{NO}_{x}, \mathrm{OH}$ was often higher while more $\mathrm{O}_{3}$ was also produced. The dominant role of $\mathrm{OH}$ oxidation in VOC loss makes the chemical scheme simple and it is easier to interpret than cases when both $\mathrm{OH}$ oxidation and ozonolysis are important.

As mentioned above, $\mathrm{RO}_{2}$ fate, i.e., the branching of $\mathrm{RO}_{2}$ loss among different pathways, has an important influence on the product distribution and thus on SOA composition, physicochemical properties, and yields. $\mathrm{RO}_{2}$ can react with $\mathrm{NO}, \mathrm{HO}_{2}$, and $\mathrm{RO}_{2} \mathrm{~s}$ or isomerize. The fate of $\mathrm{RO}_{2}$ mainly depends on the concentrations of $\mathrm{NO}, \mathrm{HO}_{2}$, and $\mathrm{RO}_{2}$. Here, the loss rates of $\mathrm{RO}_{2}$ via different pathways were quantified using the measured $\mathrm{HO}_{2}, \mathrm{NO}$, and $\mathrm{RO}_{2}$ concentrations and the rate constants based on the MCM3.3 (Jenkin et al., 1997; Saunders et al., 2003; http://mcm.leeds.ac.uk/MCM/). Measured $\mathrm{HO}_{2}$ and $\mathrm{RO}_{2}$ concentrations are shown in Fig. S7 as an example and the relative importance of different $\mathrm{RO}_{2}$ reaction pathways is compared in Fig. 1, which is similar for both $\alpha$-pinene and limonene oxidation. In the low- $\mathrm{NO}_{x}$ conditions of this study, $\mathrm{RO}_{2}+\mathrm{NO}$ dominated the $\mathrm{RO}_{2}$ loss rate in the beginning of an experiment (Fig. 1a). The trace amount of NO (up to $\sim 0.2 \mathrm{ppbV}$ ) was from the photolysis of HONO, which was continuously produced from a photolytic process on chamber walls throughout an experiment (Rohrer et al., 2005). But later in the experiment, $\mathrm{RO}_{2}+\mathrm{HO}_{2}$ contributed a significant fraction (up to $\sim 40 \%$ ) to $\mathrm{RO}_{2}$ loss because of increasing $\mathrm{HO}_{2}$ concentration and decreasing $\mathrm{NO}$ concentration. In the high- $\mathrm{NO}_{x}$ conditions, $\mathrm{RO}_{2}+\mathrm{NO}$ overwhelmingly dominated the $\mathrm{RO}_{2}$ loss rate (Fig. 1b), and, with the decrease in $\mathrm{NO}$ in an experiment, the total $\mathrm{RO}_{2}$ loss rate decreased substantially (Fig. 1b). Since the main products of $\mathrm{RO}_{2}+\mathrm{HO}_{2}$ are organic hydroperoxides, more organic hydroperoxides relative to organic nitrates are expected in the low- $\mathrm{NO}_{x}$ conditions here. The loss rate of $\mathrm{RO}_{2}+\mathrm{RO}_{2}$ was estimated to be $\sim 10^{-4} \mathrm{~s}^{-1}$ using a reaction rate constant of $2.5 \times 10^{-13}$ molecules ${ }^{-1} \mathrm{~cm}^{3} \mathrm{~s}^{-1}$ (Ziemann and Atkinson, 2012). This contribution is negligible compared to other pathways in this study, although the reaction rate constants of $\mathrm{RO}_{2}+\mathrm{RO}_{2}$ are highly uncertain and may depend on specific $\mathrm{RO}_{2}$ (Ziemann and Atkinson, 2012). Note that the $\mathrm{RO}_{2}$ fate in the low and high- $\mathrm{NO}_{x}$ conditions quantified here is further used in the discussion below since the information of the $\mathrm{RO}_{2}$ fate is important for data interpretation of experiments conducted at different $\mathrm{NO}_{x}$ levels (Wennberg, 2013).

\subsection{Effects of $\mathrm{NO}_{x}$ and $\mathrm{SO}_{2}$ on new particle formation}

The effects of $\mathrm{NO}_{x}$ and $\mathrm{SO}_{2}$ on new particle formation from $\alpha$-pinene oxidation are shown in Fig. 2a. In low- $\mathrm{SO}_{2}$ conditions, both the total particle number concentration and nucleation rate at high $\mathrm{NO}_{x}$ were lower than those at low $\mathrm{NO}_{x}$, indicating $\mathrm{NO}_{x}$ suppressed the new particle formation. The suppressing effect of $\mathrm{NO}_{x}$ on new particle formation was in agreement with the findings of Wildt et al. (2014). This suppression is considered to be caused by the increased fraction of $\mathrm{RO}_{2}+\mathrm{NO}$ reaction, decreasing the importance of $\mathrm{RO}_{2}+\mathrm{RO}_{2}$ permutation reactions. $\mathrm{RO}_{2}+\mathrm{RO}_{2}$ reaction products are believed to be involved in the new particle formation (Wildt et al., 2014; Kirkby et al., 2016) and initial growth of particles by forming higher molecular weight products such as highly oxidized multifunctional molecules (HOMs) and their dimers and trimers (Ehn et al., 2014; Kirkby et al., 2016). Although the contribution of $\mathrm{RO}_{2}+\mathrm{RO}_{2}$ reaction to the total $\mathrm{RO}_{2}$ loss is negligible, it can contribute a lot to the compounds responsible for nucleation such as dimers and trimers. Generally, organic nitrates and primary organic peroxides (from $\mathrm{RO}_{2}\left(\mathrm{C}_{10}\right)+\mathrm{HO}_{2}$ ) are not expected to be the main compounds responsible for nucleation since, although the volatility of these compounds is low (see below Sect. 3.3.1), it is likely not low enough to nucleate.

In high- $\mathrm{SO}_{2}$ conditions, the nucleation rate and total number concentrations were high, regardless of $\mathrm{NO}_{x}$ levels. The high concentration of particles was attributed to the new particle formation induced by $\mathrm{H}_{2} \mathrm{SO}_{4}$ alone formed by $\mathrm{SO}_{2}$ oxidation since the new particle formation occurred before VOC addition. The role of $\mathrm{H}_{2} \mathrm{SO}_{4}$ in new particle formation has been well studied in previous studies (Berndt et al., 2005; Zhang et al., 2012; Sipila et al., 2010; Kirkby et al., 2011; Almeida et al., 2013). 

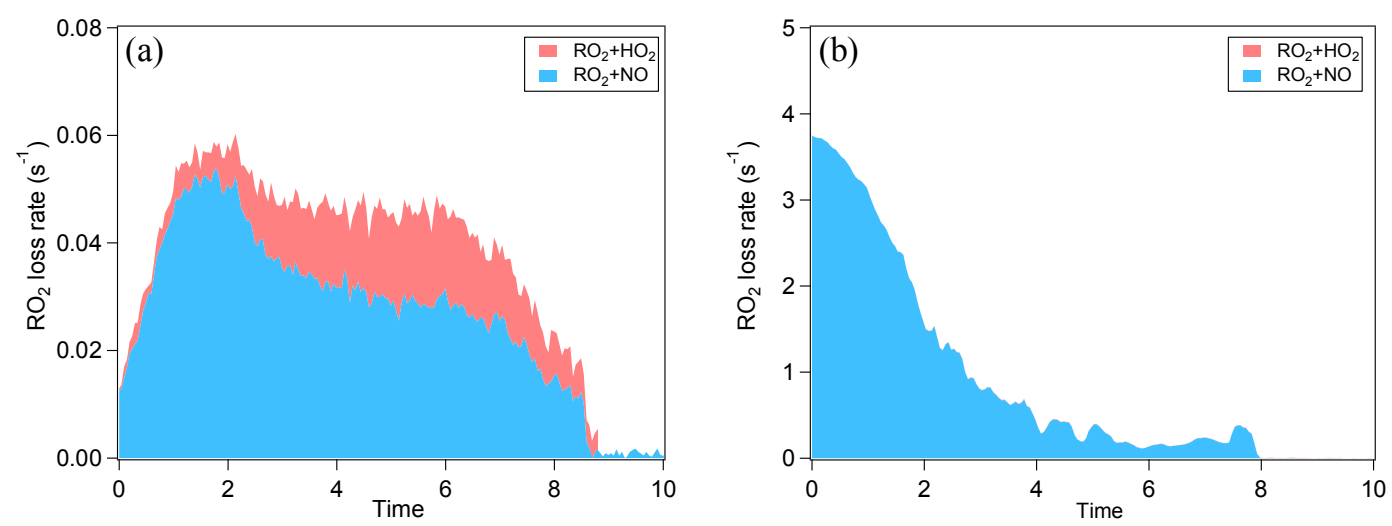

Figure 1. Typical loss rate of $\mathrm{RO}_{2}$ by $\mathrm{RO}_{2}+\mathrm{NO}$ and $\mathrm{RO}_{2}+\mathrm{HO}_{2}$ in the low- $\mathrm{NO}_{x}$ (a) and the high- $\mathrm{NO}_{x}$ (b) conditions of this study. The experiments at low $\mathrm{SO}_{2}$ are shown. The $\mathrm{RO}_{2}+\mathrm{HO}_{2}$ rate is stacked on the $\mathrm{RO}_{2}+\mathrm{NO}$ rate. Note the different scales for $\mathrm{RO}_{2}$ loss rate in panel (a) and (b). In panel (b), the contribution of $\mathrm{RO}_{2}+\mathrm{HO}_{2}$ is very low and barely noticeable.
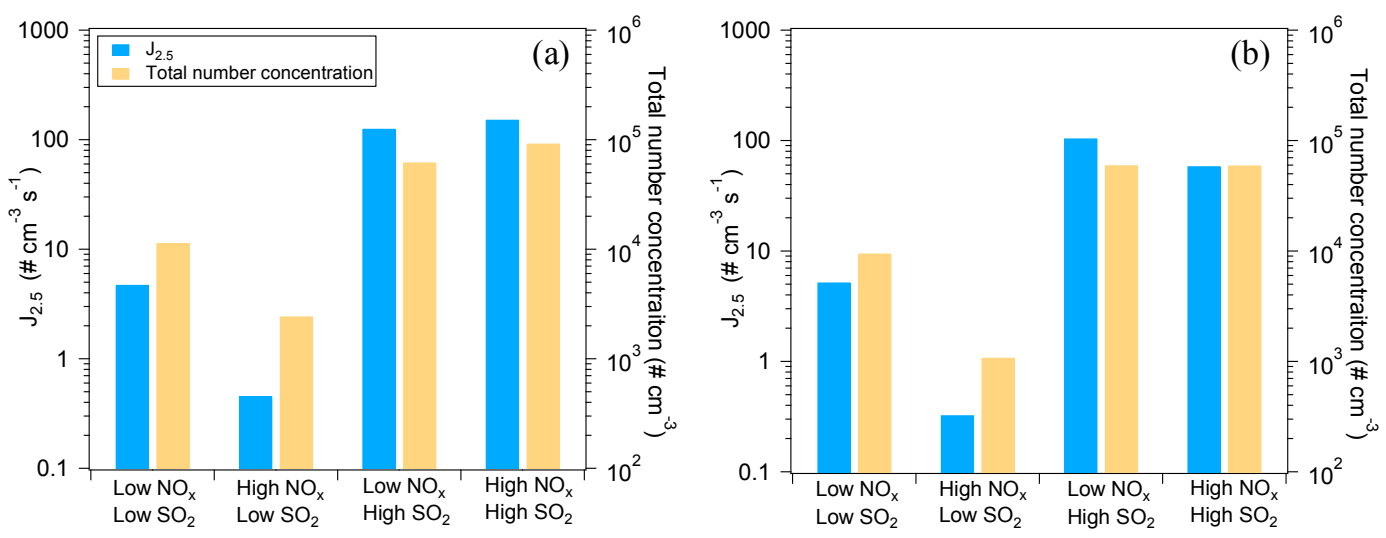

Figure 2. Nucleation rates $\left(J_{2.5}\right)$ and maximum total particle number concentrations under different $\mathrm{NO}_{x}$ and $\mathrm{SO}_{2}$ conditions for the $\mathrm{SOA}$ from $\alpha$-pinene oxidation (a) and from limonene oxidation (b).

Similar suppression of new particle formation by $\mathrm{NO}_{x}$ and enhancement of new particle formation by $\mathrm{SO}_{2}$ photooxidation were found for limonene oxidation (Fig. 2b).

\subsection{Effects of $\mathrm{NO}_{x}$ and $\mathrm{SO}_{2}$ on $\mathrm{SOA}$ mass yield}

\subsubsection{Effect of $\mathrm{NO}_{x}$}

Figure $3 \mathrm{a}$ shows SOA yield at different $\mathrm{NO}_{x}$ for $\alpha$-pinene oxidation. In order to make different experiments more comparable, the SOA yield is plotted as a function of $\mathrm{OH}$ dose instead of reaction time. In low- $\mathrm{SO}_{2}$ conditions, $\mathrm{NO}_{x}$ not only suppressed the new particle formation but also suppressed SOA mass yield. Because $\mathrm{NO}_{x}$ suppressed new particle formation, the suppression of the SOA yield could be attributed to the lack of new particles as seed, and thus the lack of condensational sink, or to the decrease in condensable organic materials. We further found that when new particle formation was already enhanced by added $\mathrm{SO}_{2}$, the SOA yield at high $\mathrm{NO}_{x}$ was comparable to that at low $\mathrm{NO}_{x}$ and the difference in $\mathrm{SOA}$ yield between high $\mathrm{NO}_{x}$ and low
$\mathrm{NO}_{x}$ was much smaller (Fig. 3a). This finding can be attributed to two possible explanations. Firstly, $\mathrm{NO}_{x}$ did not significantly suppress the formation of low-volatility condensable organic materials, although $\mathrm{NO}_{x}$ obviously suppressed the formation of products for nucleation. Secondly, $\mathrm{NO}_{x}$ did suppress the formation of low-volatility condensable organic materials via forming potentially more volatile compounds and, in addition to that, the suppressed formation of condensable organic materials was compensated for by the presence of $\mathrm{SO}_{2}$, resulting in comparable SOA yield. Organic nitrates are a group of compounds formed at high $\mathrm{NO}_{x}$, which have been proposed to be more volatile (Presto et al., 2005; Kroll et al., 2006). However, many organic nitrates formed by photooxidation in this study were highly oxidized organic molecules containing multifunctional groups besides nitrate group $\left(\mathrm{C}_{7-10} \mathrm{H}_{9-15} \mathrm{NO}_{8-15}\right.$, HOMs nitrate). These compounds are expected to have low volatility and they are found to have an uptake coefficient on particles of $\sim 1$ (Pullinen et al., 2018). Therefore, the suppressing effect of $\mathrm{NO}_{x}$ on SOA yield was mostly likely due to suppressed 

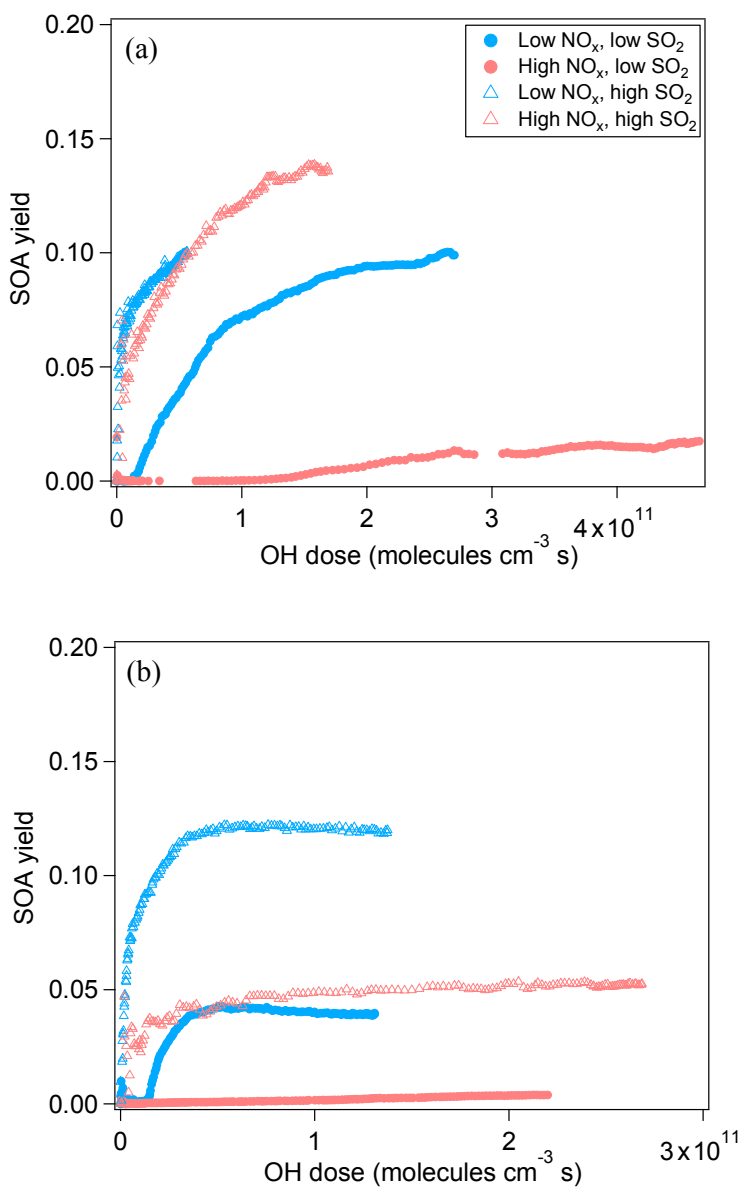

Figure 3. SOA yield of the photooxidation of $\alpha$-pinene (a) and limonene (b) in different $\mathrm{NO}_{x}$ and $\mathrm{SO}_{2}$ conditions.

nucleation, i.e., the lack of particle surface as condensational sink. Due to the low particle surface area, the wall loss of condensable vapors in the experiment at high $\mathrm{NO}_{x}$ and low $\mathrm{SO}_{2}$ was large (as shown by the large $f_{\text {corr }}$ in Fig. S4) and therefore SOA mass yield was suppressed. If vapor wall loss is considered, the difference between the SOA yield at high $\mathrm{NO}_{x}$ and at low $\mathrm{NO}_{x}$ under low- $\mathrm{SO}_{2}$ conditions will be much reduced, as we found for high- $\mathrm{SO}_{2}$ cases (Fig. 3a). Under high- $\mathrm{SO}_{2}$ conditions, the influence of vapor wall loss on the difference in $\mathrm{SOA}$ yield between high $\mathrm{NO}_{x}$ and low $\mathrm{NO}_{x}$ was minor (1-8\%, Fig. S4) due to the larger particle surface area.

For limonene oxidation, similar results of $\mathrm{NO}_{x}$ suppressing the particle mass formation have been found in low- $\mathrm{SO}_{2}$ conditions (Fig. 3b). Yet, in high-SO $\mathrm{SO}_{2}$ conditions, the $\mathrm{SOA}$ yield from limonene oxidation at high $\mathrm{NO}_{x}$ was still significantly lower than that at low $\mathrm{NO}_{x}$, which is different from the findings for $\alpha$-pinene SOA. The cause of this difference is currently unknown. Our data of SOA yield suggest that the products formed from limonene oxidation at high $\mathrm{NO}_{x}$ seemed to have higher average volatility than that at low $\mathrm{NO}_{x}$.
The suppression of SOA mass formation by $\mathrm{NO}_{x}$ under low- $\mathrm{SO}_{2}$ conditions agrees with previous studies (Eddingsaas et al., 2012a; Wildt et al., 2014; Sarrafzadeh et al., 2016; Hatakeyama et al., 1991). For example, it was found that high concentration of $\mathrm{NO}_{x}$ (tens of ppb) suppressed mass yield of SOA formed from photooxidation of $\beta$-pinene, $\alpha$ pinene, and VOC emitted by Mediterranean trees (Wildt et al., 2014; Sarrafzadeh et al., 2016). And on the basis of the results by Eddingsaas et al. (2012a), the SOA yield at high $\mathrm{NO}_{x}$ (referred to as high $\mathrm{NO}$ by the authors) is lower than at low $\mathrm{NO}_{x}$ in the absence of seed aerosol.

Our finding that the difference in SOA yield between high$\mathrm{NO}_{x}$ and low- $\mathrm{NO}_{x}$ conditions was highly reduced at high $\mathrm{SO}_{2}$ is also in line with the findings of some previous studies using seed aerosols (Sarrafzadeh et al., 2016; Eddingsaas et al., 2012a). For example, Sarrafzadeh et al. (2016) found that, in the presence of seed aerosol, the suppressing effect of $\mathrm{NO}_{x}$ on the SOA yield from $\beta$-pinene photooxidation is substantially diminished and SOA yield only decreases by $20-30 \%$ in the $\mathrm{NO}_{x}$ range of $<1$ to $86 \mathrm{ppb}$ at constant $\mathrm{OH}$ concentrations. The data by Eddingsaas et al. (2012a) also showed that, in the presence of seed aerosol, the difference in the SOA yield between low $\mathrm{NO}_{x}$ and high $\mathrm{NO}_{x}$ is much decreased. However, our finding is in contrast with the findings in other studies (Presto et al., 2005; Ng et al., 2007; Han et al., 2016; Stirnweis et al., 2017), who reported much lower $\mathrm{SOA}$ yield at high $\mathrm{NO}_{x}$ than at low $\mathrm{NO}_{x}$ in the presence of seed. The different findings in these studies from ours may be attributed to the difference in the reaction conditions such as VOC oxidation pathways ( $\mathrm{OH}$ oxidation vs. ozonolysis), VOC and $\mathrm{NO}_{x}$ concentration ranges, $\mathrm{NO} / \mathrm{NO}_{2}, \mathrm{OH}$ concentrations, and organic aerosol loading, which all affect SOA yield. The reaction conditions of this study often differ from those described in the literature (see Table S2).

The difference in these conditions can result in both different apparent dependence on specific parameters and the varied SOA yield. For example, SOA yield from $\alpha$-pinene photooxidation at low $\mathrm{NO}_{x}$ in this study appeared to be much lower than that in Eddingsaas et al. (2012a). The difference between the SOA yield in this study and some of previous studies and between the values in the literature can be attributed to several reasons: (1) $\mathrm{RO}_{2}$ fates may be different. For example, in our study at low $\mathrm{NO}_{x}, \mathrm{RO}_{2}+\mathrm{NO}$ account for a large fraction of $\mathrm{RO}_{2}$ loss while in Eddingsaas et al. (2012a) $\mathrm{RO}_{2}+\mathrm{HO}_{2}$ is the dominant pathway of $\mathrm{RO}_{2}$ loss. This difference in $\mathrm{RO}_{2}$ fates may affect oxidation products' distribution. (2) The organic aerosol loading of this study is much lower than that of some previous studies (e.g., Eddingsaas et al., 2012a; see Fig. S9). SOA yields in this study were also plotted versus organic aerosol loading to better compare with previous studies (Figs. S8 and S9). (3) The total particle surface area in this study may also differ from previous studies, which may influence the apparent SOA yield due to vapor wall loss (the total particle surface area is often not reported in many previous studies to compare with). (4) $\mathrm{RH}$ of this 
study is different from many previous studies, which often used very low $\mathrm{RH}(<10 \%)$. It is important to emphasize that reaction conditions including the $\mathrm{NO}_{x}$ as well as $\mathrm{SO}_{2}$ concentration range and $\mathrm{RH}$ in this study were chosen to be relevant to the anthropogenic-biogenic interactions in the ambient atmosphere. In addition, the difference in the organic aerosol density used in yield calculation should be taken into account. In this study, SOA yield was derived using a density of $1 \mathrm{~g} \mathrm{~cm}^{-3}$ to better compare with many previous studies (e.g., Henry et al., 2012), while in some other studies SOA yield was derived using different density (e.g., $1.32 \mathrm{~g} \mathrm{~cm}^{-3}$ in Eddingsaas et al., 2012a).

\subsubsection{Effect of $\mathrm{SO}_{2}$}

For both $\alpha$-pinene and limonene, $\mathrm{SO}_{2}$ was found to enhance the SOA mass yield at given $\mathrm{NO}_{x}$ levels, especially for the high- $\mathrm{NO}_{x}$ cases (Fig. 3). The enhancing effect of $\mathrm{SO}_{2}$ on particle mass formation can be attributed to two reasons. Firstly, $\mathrm{SO}_{2}$ oxidation induced new particle formation, which provided more surface and volume for further condensation of organic vapors. This is consistent with the finding that the enhancement of SOA yield by $\mathrm{SO}_{2}$ was more significant at high $\mathrm{NO}_{x}$ when the enhancement in nucleation was also more significant. Secondly, $\mathrm{H}_{2} \mathrm{SO}_{4}$ formed by photooxidation of $\mathrm{SO}_{2}$ can enhance SOA formation via acid-catalyzed heterogeneous uptake, an important SOA formation pathway initially found from isoprene photooxidation (Jang et al., 2002; Lin et al., 2012; Surratt et al., 2007) and later also in the photooxidation of other compounds such as anthropogenic VOC (Chu et al., 2016; Liu et al., 2016). For the products from monoterpene oxidation, such an acid-catalyzed effect may also occur (Northcross and Jang, 2007; Wang et al., 2012; Lal et al., 2012; Zhang et al., 2006; Ding et al., 2011; Iinuma et al., 2009) and, in this study, the particles were acidic with the molar ratio of $\mathrm{NH}_{4}^{+}$to $\mathrm{SO}_{4}^{2-}$ around 1.5-1.8, although no aqueous phase was formed.

We found that the SOA yield in the limonene oxidation at a moderate $\mathrm{SO}_{2}$ level (2 ppb) was comparable to the yield at high $\mathrm{SO}_{2}(15 \mathrm{ppb})$ when similar particle number concentrations in both cases were formed. Both yields were significantly higher than the yield at low $\mathrm{SO}_{2}(<0.05 \mathrm{ppb}$, see Fig. S10). This comparison suggests that the effect on enhancing new particle formation by $\mathrm{SO}_{2}$ seems to be more important compared to the particle acidity effect. The role of $\mathrm{SO}_{2}$ in new particle formation is similar to adding seed aerosol and providing particle surface for organics to condense. Artificially added seed aerosol has been shown to enhance SOA formation from $\alpha$-pinene and $\beta$-pinene oxidation (Ehn et al., 2014; Sarrafzadeh et al., 2016; Eddingsaas et al., 2012a). In some other studies, it was found that the SOA yield from $\alpha$-pinene oxidation is independent of initial seed surface area (McVay et al., 2016; Nah et al., 2016). The difference in the literature may be due to the range of the total surface area of particles, reaction conditions, and chamber setup. For example, the peak particle-to-chamber surface ratio for $\alpha$-pinene photooxidation in this study was $7.7 \times 10^{-5}$ at high $\mathrm{NO}_{x}$ and low $\mathrm{SO}_{2}$, much lower than the aerosol surface area range in the studies by Nah et al. (2016) and McVay et al. (2016). A lower particle-to-chamber surface ratio can lead to a larger fraction of organics lost on chamber walls. Hence, providing additional particle surface by adding seed particles can increase the condensation of organics on particles and thus increase SOA yield. However, once the surface area is high enough to inhibit condensation of vapors on chamber walls, further enhancement of particle surface will not significantly enhance the yield (Sarrafzadeh et al., 2016).

As mentioned above, the SOA yield at high $\mathrm{NO}_{x}$ and low $\mathrm{SO}_{2}$ was significantly suppressed due to vapor wall loss. If the influence of vapor wall loss is considered, the SOA yield at high $\mathrm{NO}_{x}$ and low $\mathrm{SO}_{2}$ will be much higher and thus the observed enhancement of SOA yield by $\mathrm{SO}_{2}$ under high$\mathrm{NO}_{x}$ conditions will be much less pronounced. Under low$\mathrm{NO}_{x}$ conditions, the influence of vapor wall loss on the difference in $\mathrm{SOA}$ yield between high $\mathrm{SO}_{2}$ and low $\mathrm{SO}_{2}$ was minor $(1-7 \%$ for $\alpha$-pinene and $5-32 \%$ for limonene, see Fig. S4) due to the larger particle surface area.

Particle acidity may also play a role in affecting the SOA yield in the experiments with high $\mathrm{SO}_{2}$. Particle acidity was found to enhance the SOA yield from $\alpha$-pinene photooxidation at high- $\mathrm{NO}_{x}$ (Offenberg et al., 2009) and high-NO conditions (Eddingsaas et al., 2012a). Yet, in low- $\mathrm{NO}_{x}$ condition, particle acidity was reported to have no significant effect on the SOA yield from $\alpha$-pinene photooxidation (Eddingsaas et al., 2012a; Han et al., 2016). According to these findings, at low $\mathrm{NO}_{x}$ the enhancement of SOA yield in this study is attributed to the effect of facilitating nucleation and providing more particle surface by $\mathrm{SO}_{2}$ photooxidation. At high $\mathrm{NO}_{x}$, the effect on enhancing new particle formation by $\mathrm{SO}_{2}$ photooxidation seems to be more important, although the effect of particle acidity resulted from $\mathrm{SO}_{2}$ photooxidation may also play a role.

$\mathrm{SO}_{2}$ has been proposed to also affect gas-phase chemistry of organics by changing the $\mathrm{HO}_{2} / \mathrm{OH}$ or forming $\mathrm{SO}_{3}$ (Friedman et al., 2016). In this study, the effect of $\mathrm{SO}_{2}$ on gas-phase chemistry of organics was not significant because of the much lower reactivity of $\mathrm{SO}_{2}$ with $\mathrm{OH}$ compared with $\alpha$-pinene and limonene (Atkinson et al., 2004, 2006; Atkinson and Arey, 2003) and the low $\mathrm{OH}$ concentrations (2-3 orders of magnitude lower than those in the study by Friedman et al., 2016). Moreover, reactions of $\mathrm{RO}_{2}$ with $\mathrm{SO}_{2}$ were also not important because the reaction rate constant is very low $\left(<10^{-14}\right.$ molecule $^{-1} \mathrm{~cm}^{3} \mathrm{~s}^{-1}$; Lightfoot et al., 1992; Berndt et al., 2015). In addition, from the AMS data of SOA formed at high $\mathrm{SO}_{2}$ no significant organic fragments containing sulfur were found. Also the fragment $\mathrm{CH}_{3} \mathrm{SO}_{2}^{+}$from organic sulfate suggested by Farmer et al. (2010) was not detected in our data. The absence of organic sulfate tracers is likely due to the lack of aqueous phase in aerosol particles in this study. Therefore, the influence of $\mathrm{SO}_{2}$ on gas-phase chemistry of 
organics and further on SOA yield via affecting gas-phase chemistry is not important in this study.

The presence of high $\mathrm{SO}_{2}$ enhanced the SOA mass yield at high- $\mathrm{NO}_{x}$ conditions, which was even comparable with the SOA yield at low $\mathrm{NO}_{x}$ for $\alpha$-pinene oxidation. This finding indicates that the suppressing effect of $\mathrm{NO}_{x}$ on SOA mass formation was compensated for to a large extent by the presence of $\mathrm{SO}_{2}$. This has important implications for SOA formation affected by anthropogenic-biogenic interactions in the real atmosphere when $\mathrm{SO}_{2}$ and $\mathrm{NO}_{x}$ often coexist in relatively high concentrations as discussed below.

\subsection{Effects of $\mathrm{NO}_{x}$ and $\mathrm{SO}_{2}$ on $\mathrm{SOA}$ chemical composition}

The effects of $\mathrm{NO}_{x}$ and $\mathrm{SO}_{2}$ on $\mathrm{SOA}$ chemical composition were analyzed on the basis of AMS data. We found that $\mathrm{NO}_{x}$ enhanced nitrate formation. The ratio of the mass of nitrate to organics was higher at high $\mathrm{NO}_{x}$ than at low $\mathrm{NO}_{x}$ regardless of the $\mathrm{SO}_{2}$ level, and similar trends were found for SOA from $\alpha$-pinene and limonene oxidation (Fig. 4a). Higher nitrate to organics ratios were observed for SOA from limonene at high $\mathrm{NO}_{x}$, which is mainly due to the lower $\mathrm{VOC} / \mathrm{NO}_{x}$ ratio resulted from the lower concentrations of limonene (7 ppb) compared to $\alpha$-pinene (20 ppb) (see Table 1 ). Overall, the mass ratios of nitrate to organics ranged from 0.02 to 0.11 considering all the experiments in this study.

Nitrate formed can be either inorganic (such as $\mathrm{HNO}_{3}$ from the reaction of $\mathrm{NO}_{2}$ with $\mathrm{OH}$ ) or organic (from the reaction of $\mathrm{RO}_{2}$ with $\left.\mathrm{NO}\right)$. The ratio of $\mathrm{NO}_{2}^{+}(\mathrm{m} / z=46)$ to $\mathrm{NO}^{+}(m / z=30)$ in the mass spectra detected by AMS can be used to differentiate whether nitrate is organic or inorganic (Fry et al., 2009; Rollins et al., 2009; Farmer et al., 2010; Kiendler-Scharr et al., 2016). Organic nitrate was considered to have a $\mathrm{NO}_{2}^{+} / \mathrm{NO}^{+}$of $\sim 0.1$ and inorganic $\mathrm{NH}_{4} \mathrm{NO}_{3}$ had a $\mathrm{NO}_{2}^{+} / \mathrm{NO}^{+}$of $\sim 0.31$ with the instrument used in this study as determined from calibration measurements. In this study, $\mathrm{NO}_{2}^{+} / \mathrm{NO}^{+}$ratios ranged from 0.14 to 0.18 , closer to the ratio of organic nitrate. The organic nitrate was estimated to account for 57-77\% (molar fraction) of total nitrate considering both the low- $\mathrm{NO}_{x}$ and high- $\mathrm{NO}_{x}$ conditions. This indicates that nitrate was mostly organic nitrate, even at low $\mathrm{NO}_{x}$ in this study.

In order to determine the contribution of organic nitrate to total organics, we estimated the molecular weight of organic nitrates formed by $\alpha$-pinene and limonene oxidation to be $200-300 \mathrm{~g} \mathrm{~mol}^{-1}$, based on reaction mechanisms (Eddingsaas et al., 2012b, and MCM v3.3 at http://mcm.leeds.ac. $\mathrm{uk} / \mathrm{MCM}$ ). We assumed a molecular weight of $200 \mathrm{~g} \mathrm{~mol}^{-1}$ in order to make our results comparable to the field studies which used similar molecular weight (Kiendler-Scharr et al., 2016). For this value, the organic nitrate compounds were estimated to account for $7-26 \%$ of the total organics mass as measured by AMS in SOA. Organic nitrate fraction in total organics was within the range of values found in a field ob- servation in southeast US (5-12\% in summer and 9-25\% in winter depending on the molecular weight of organic nitrate) using AMS (Xu et al., 2015b) and particle organic nitrate content derived from the sum of speciated organic nitrates (around 1-17\% considering observed variability and 3 and $8 \%$ on average in the afternoon and at night, respectively; Lee et al., 2016). Note that the organic nitrate fraction observed in this study was lower than the mean value (42\%) for a number of European observation stations when organic nitrate is mainly formed by the reaction of $\mathrm{VOC}$ with $\mathrm{NO}_{3}$ (Kiendler-Scharr et al., 2016).

Moreover, we found that the contribution of organic nitrate to total organics (calculated using a molecular weight of $200 \mathrm{~g} \mathrm{~mol}^{-1}$ for organic nitrate) was higher at high $\mathrm{NO}_{x}$ (Fig. 4b), although in some experiments the ratios of $\mathrm{NO}_{2}^{+}$to $\mathrm{NO}^{+}$were too noisy to derive a reliable fraction of organic nitrate. This result is consistent with the reaction scheme that at high $\mathrm{NO}_{x}$ almost all the $\mathrm{RO}_{2}$ loss was switched to the reaction with NO, which is expected to enhance the organic nitrate formation. In addition to organic nitrate, the ratio of nitrogen to carbon atoms $(\mathrm{N} / \mathrm{C})$ was also found to be higher at high $\mathrm{NO}_{x}$ (Fig. S11). But after considering the nitrate functional group separately, the $\mathrm{N} / \mathrm{C}$ ratio was very low, generally $<0.01$, which indicates that a majority of the organic nitrogen existed in the form of organic nitrate.

The chemical composition of organic components of SOA in terms of $\mathrm{H} / \mathrm{C}$ and $\mathrm{O} / \mathrm{C}$ ratios at different $\mathrm{NO}_{x}$ and $\mathrm{SO}_{2}$ levels was further compared. For SOA from $\alpha$-pinene photooxidation, in low- $\mathrm{SO}_{2}$ conditions, no significant difference in $\mathrm{H} / \mathrm{C}$ and $\mathrm{O} / \mathrm{C}$ was found between SOA formed at low $\mathrm{NO}_{x}$ and at high $\mathrm{NO}_{x}$ within the experimental uncertainties (Fig. 5). The variability of $\mathrm{H} / \mathrm{C}$ and $\mathrm{O} / \mathrm{C}$ at high $\mathrm{NO}_{x}$ is large, mainly due to the low particle mass and small particle size. In high- $\mathrm{SO}_{2}$ conditions, SOA formed at high $\mathrm{NO}_{x}$ had the higher $\mathrm{O} / \mathrm{C}$ and lower $\mathrm{H} / \mathrm{C}$, which indicates that SOA components had higher oxidation state. The higher $\mathrm{O} / \mathrm{C}$ at high $\mathrm{NO}_{x}$ than at low $\mathrm{NO}_{x}$ is partly due to the higher $\mathrm{OH}$ dose at high $\mathrm{NO}_{x}$, although even at the same $\mathrm{OH}$ dose $\mathrm{O} / \mathrm{C}$ at high $\mathrm{NO}_{x}$ was still slightly higher than at low $\mathrm{NO}_{x}$ in high$\mathrm{SO}_{2}$ conditions.

For the SOA formed from limonene photooxidation, no significant difference in the $\mathrm{H} / \mathrm{C}$ and $\mathrm{O} / \mathrm{C}$ was found between different $\mathrm{NO}_{x}$ and $\mathrm{SO}_{2}$ conditions (Fig. S12), which is partly due to the low signal resulting from low particle mass and small particle size in high- $\mathrm{NO}_{x}$ conditions.

Due to the high uncertainties for some of the $\mathrm{H} / \mathrm{C}$ and $\mathrm{O} / \mathrm{C}$ data, the chemical composition was further analyzed using $f_{44}$ and $f_{43}$ since $f_{44}$ and $f_{43}$ are less noisy (Fig. 6). For both $\alpha$-pinene and limonene, SOA formed at high $\mathrm{NO}_{x}$ generally had lower $f_{43}$. Because $f_{43}$ generally correlates with $\mathrm{H} / \mathrm{C}$ in organic aerosol ( $\mathrm{Ng}$ et al., 2011), lower $f_{43}$ is indicative of lower $\mathrm{H} / \mathrm{C}$, which is consistent with the lower $\mathrm{H} / \mathrm{C}$ at high $\mathrm{NO}_{x}$ observed for SOA from $\alpha$-pinene oxidation in high- $\mathrm{SO}_{2}$ conditions (Fig. 5). The lower $f_{43}$ at high $\mathrm{NO}_{x}$ was evidenced in the oxidation of $\alpha$-pinene based 

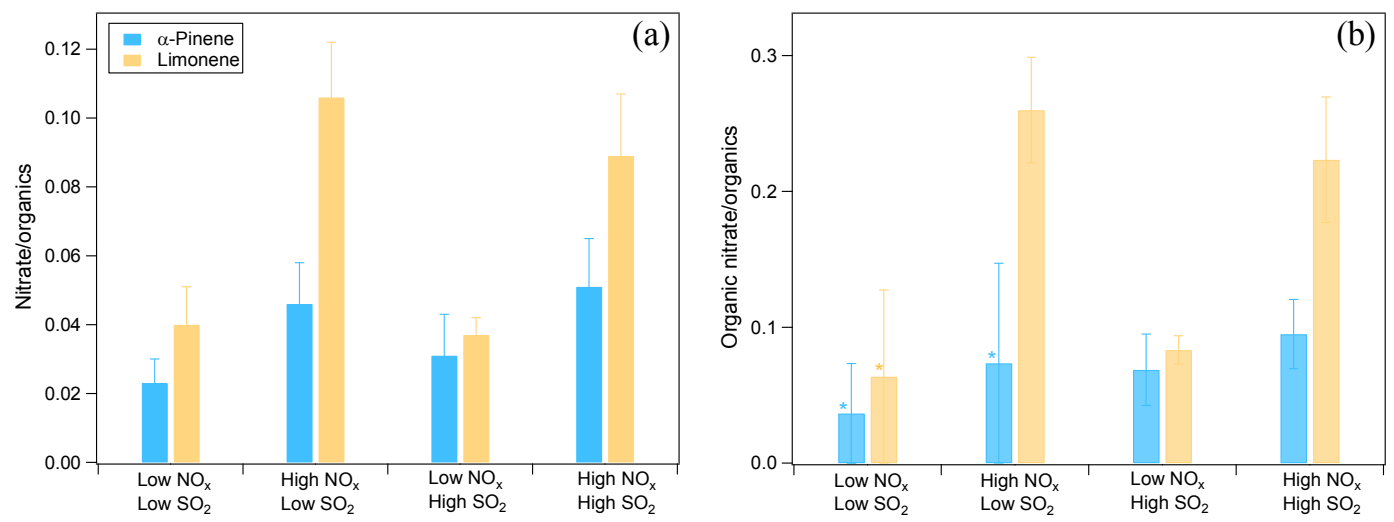

Figure 4. (a) The ratio of nitrate mass concentration to organics mass in different $\mathrm{NO}_{x}$ and $\mathrm{SO}_{2}$ conditions. The average ratios of nitrate to organics during the reaction are shown and error bars indicate the standard deviations. (b) The fraction of organic nitrate to total organics in different $\mathrm{NO}_{x}$ and $\mathrm{SO}_{2}$ conditions calculated using a molecular weight of $200 \mathrm{~g} \mathrm{~mol}^{-1}$ for organic nitrate. The average fractions during the reaction are shown and error bars indicate the standard deviations. In panel (b), ${ }^{*}$ indicates the experiments where the ratios of $\mathrm{NO}_{2}^{+}$to $\mathrm{NO}^{+}$ were too noisy to derive a reliable fraction of organic nitrate. For these experiments, $50 \%$ of total nitrate was assumed to be organic nitrate and the error bars show the range when 0 to $100 \%$ of nitrate is assumed to be organic nitrate.
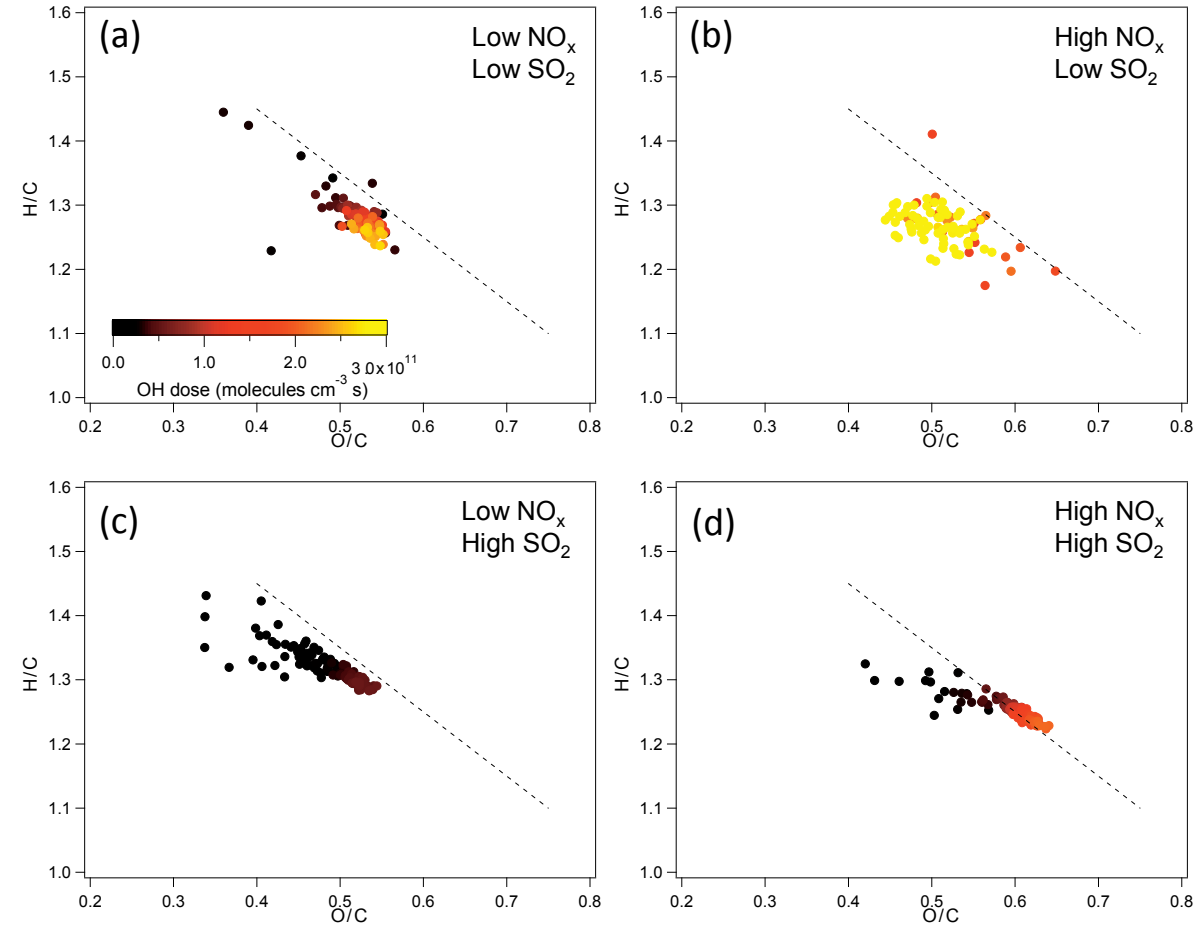

Figure 5. $\mathrm{H} / \mathrm{C}$ and $\mathrm{O} / \mathrm{C}$ ratio of SOA from photooxidation of $\alpha$-pinene in different $\mathrm{NO}_{x}$ and $\mathrm{SO}_{2}$ conditions. (a) $\mathrm{Low} \mathrm{NO}_{x}$, low $\mathrm{SO}_{2}$; (b) high $\mathrm{NO}_{x}$, low $\mathrm{SO}_{2}$; (c) low $\mathrm{NO}_{x}$, high $\mathrm{SO}_{2}$; (d) high $\mathrm{NO}_{x}$, high $\mathrm{SO}_{2}$. The black dashed line corresponds to the slope of -1 .

on the data in a previous study (Chhabra et al., 2011). The lower $\mathrm{H} / \mathrm{C}$ and $f_{43}$ are likely to be related to the reaction pathways. According to the reaction mechanism mentioned above, at low $\mathrm{NO}_{x}$ a significant fraction of $\mathrm{RO}_{2}$ reacted with $\mathrm{HO}_{2}$, forming hydroperoxides, while at high $\mathrm{NO}_{x}$ almost all $\mathrm{RO}_{2}$ reacted with $\mathrm{NO}$, forming organic nitrates. Compared with organic nitrates, hydroperoxides have a higher $\mathrm{H} / \mathrm{C}$ ra- tio. The same mechanism also caused higher organic nitrate fraction at high $\mathrm{NO}_{x}$, as discussed above.

Detailed mass spectra of SOA were compared, shown in Fig. 7. For $\alpha$-pinene, in high- $\mathrm{SO}_{2}$ conditions, mass spectra of SOA formed at high $\mathrm{NO}_{x}$ generally had higher intensity for CHOgt1 ("gt1" means greater than 1) family ions, such as $\mathrm{CO}_{2}^{+}(m / z 44)$, but lower intensity for $\mathrm{CH}$ family ions, 

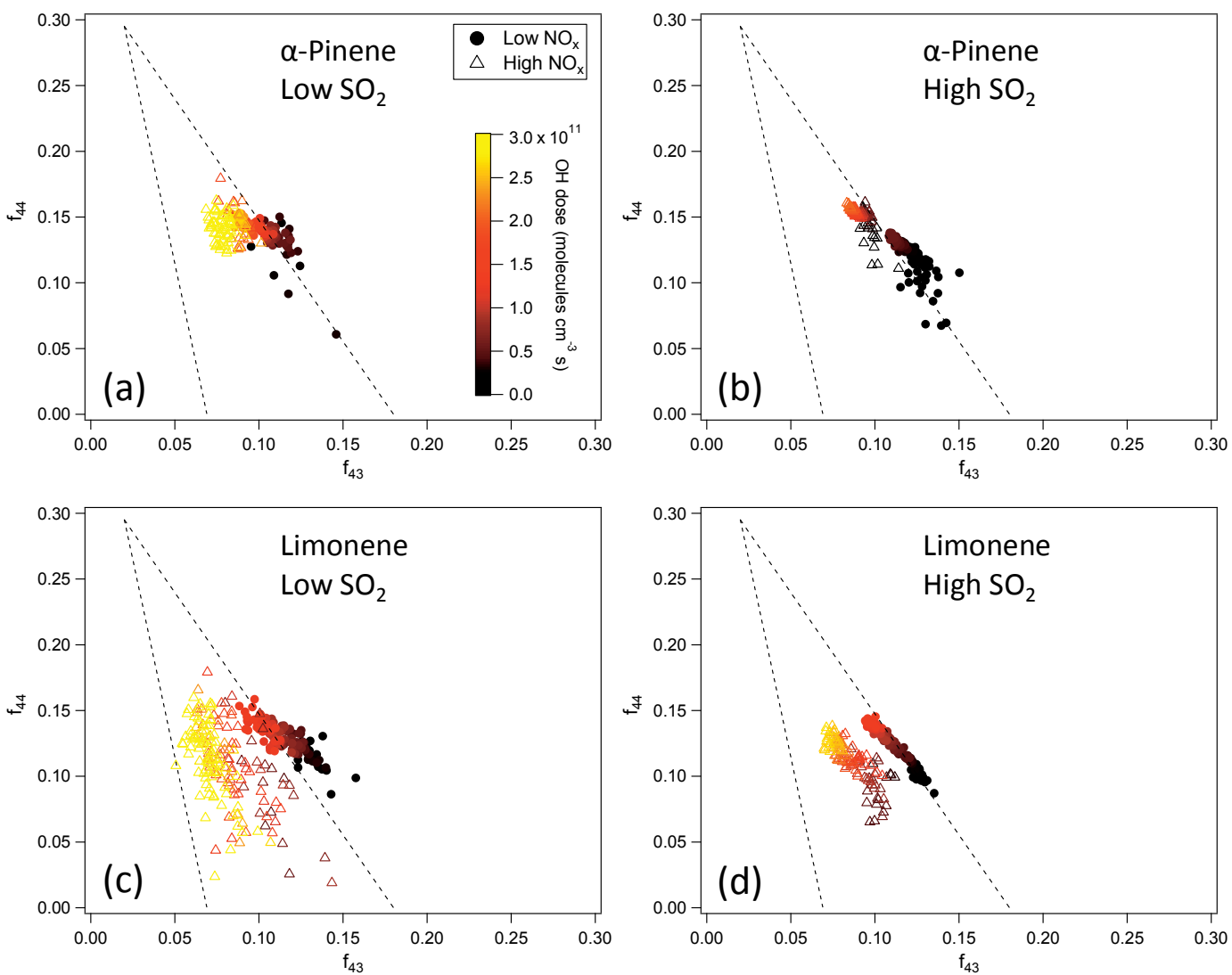

Figure 6. $f_{44}$ and $f_{43}$ of SOA from the photooxidation of $\alpha$-pinene and limonene in different $\mathrm{NO}_{x}$ and $\mathrm{SO}_{2}$ conditions. (a) $\alpha$-Pinene, low $\mathrm{SO}_{2}$; (b) $\alpha$-pinene, high $\mathrm{SO}_{2}$; (c) limonene, low $\mathrm{SO}_{2}$; (d) limonene, high $\mathrm{SO}_{2}$. Note that in the low-SO $\mathrm{SO}_{2}$, high-NO - condition (c), the AMS signal of SOA from limonene oxidation was too low to derive reliable information due to the low particle mass concentration and small particle size. Therefore, the data for high $\mathrm{NO}_{x}$ in (c) show an experiment with moderate $\mathrm{SO}_{2}(2 \mathrm{ppb})$ and high $\mathrm{NO}_{x}$ instead.

such as $\mathrm{C}_{2} \mathrm{H}_{3}^{+}(m / z 15)$ and $\mathrm{C}_{3} \mathrm{H}_{3}^{+}(m / z 39$; Fig. $7 \mathrm{~b})$, than at low $\mathrm{NO}_{x}$. In low-SO $\mathrm{SO}_{2}$ conditions, such difference is not apparent (Fig. 7a), partly due to the low signal from AMS for SOA formed at high $\mathrm{NO}_{x}$ as discussed above. For both the high- $\mathrm{SO}_{2}$ and low- $\mathrm{SO}_{2}$ cases, mass spectra of SOA at high $\mathrm{NO}_{x}$ show higher intensity of CHN1 family ions. This is also consistent with the higher $\mathrm{N} / \mathrm{C}$ ratio shown above. For SOA from limonene oxidation, SOA formed at high $\mathrm{NO}_{x}$ had a lower mass fraction at $m / z 15\left(\mathrm{C}_{2} \mathrm{H}_{3}^{+}\right), 28\left(\mathrm{CO}^{+}\right)$, $43\left(\mathrm{C}_{2} \mathrm{H}_{3} \mathrm{O}^{+}\right)$, and $44\left(\mathrm{CO}_{2}^{+}\right)$and a higher mass fraction at $m / z 27\left(\mathrm{CHN}^{+}, \mathrm{C}_{2} \mathrm{H}_{3}^{+}\right), 41\left(\mathrm{C}_{3} \mathrm{H}_{5}^{+}\right), 55\left(\mathrm{C}_{4} \mathrm{H}_{7}^{+}\right)$, and 64 $\left(\mathrm{C}_{4} \mathrm{O}^{+}\right)$than at low $\mathrm{NO}_{x}$ (Fig. S13). It seems that overall mass spectra of the SOA from limonene formed at high $\mathrm{NO}_{x}$ had higher intensity for $\mathrm{CH}$ family ions, but lower intensity for $\mathrm{CHO} 1$ family ions than at low $\mathrm{NO}_{x}$. Note that the differences in these $m / z$ values were based on the average spectra during the whole reaction period and may not reflect the chemical composition at a certain time.

\section{Conclusion and implications}

We investigated the SOA formation from the photooxidation of $\alpha$-pinene and limonene under different $\mathrm{NO}_{x}$ and $\mathrm{SO}_{2}$ conditions, when $\mathrm{OH}$ oxidation was the dominant oxidation pathway of monoterpenes. The fate of $\mathrm{RO}_{2}$ was regulated by varying $\mathrm{NO}_{x}$ concentrations. We confirmed that $\mathrm{NO}_{x}$ suppressed new particle formation. $\mathrm{NO}_{x}$ also suppressed SOA mass yield in the absence of $\mathrm{SO}_{2}$. The suppression of SOA yield by $\mathrm{NO}_{x}$ was likely due to the suppressed new particle formation, i.e., absence of sufficient particle surfaces for organic vapor to condense on at high $\mathrm{NO}_{x}$, which could result in large vapor loss to chamber walls.

$\mathrm{SO}_{2}$ enhanced SOA yield from $\alpha$-pinene and limonene photooxidation. $\mathrm{SO}_{2}$ oxidation produced a high number concentration of particles and compensated for the suppression of SOA yield by $\mathrm{NO}_{x}$ to a large extent. The enhancement of SOA yield by $\mathrm{SO}_{2}$ is likely to be mainly caused by facilitating nucleation by $\mathrm{H}_{2} \mathrm{SO}_{4}$, although the contribution of acid-catalyzed heterogeneous uptake cannot be excluded.

$\mathrm{NO}_{x}$ promoted nitrate formation. The majority (57-77\%) of nitrate was organic nitrate at both low $\mathrm{NO}_{x}$ and high 


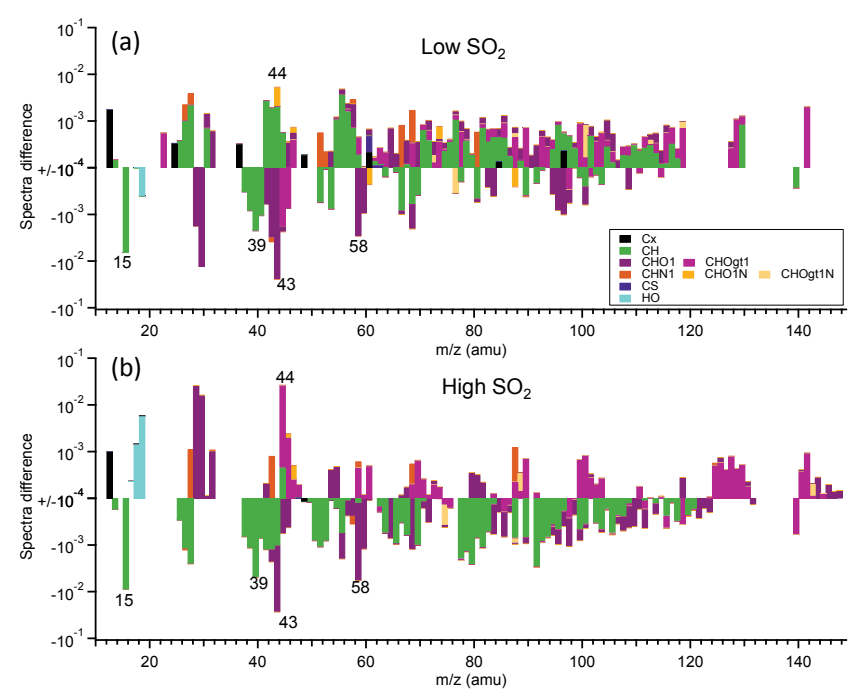

Figure 7. The difference in the mass spectra of organics of SOA from $\alpha$-pinene photooxidation between high- $\mathrm{NO}_{x}$ and low$\mathrm{NO}_{x}$ conditions (high $\mathrm{NO}_{x}-$ low $\mathrm{NO}_{x}$ ). SOA was formed at low $\mathrm{SO}_{2}$ (a) and high $\mathrm{SO}_{2}$ (b). The different chemical families of highresolution mass peaks are stacked at each unit mass $m / z$ ("gt1" means greater than 1). The mass spectra were normalized to the total organic signals. Note the log scale of the $y$ axis and only the data with absolute values large than $10^{-4}$ are shown.

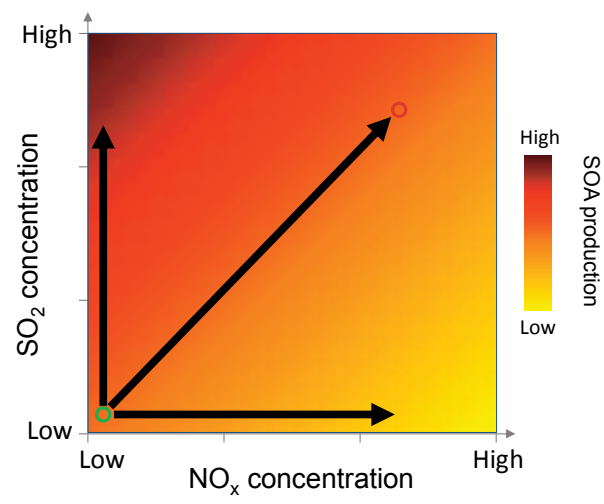

Figure 8. Conceptual schematic showing how $\mathrm{NO}_{x}$ and $\mathrm{SO}_{2}$ concentrations affect biogenic SOA mass production. The darker colors indicate higher SOA production. The circle on the bottom left corner indicates biogenic cases and the circle on the right top corner indicates the anthropogenic cases. And the horizontal and vertical arrows indicate the effect of $\mathrm{NO}_{x}$ and $\mathrm{SO}_{2}$ alone. The overall effects on SOA production depend on specific $\mathrm{NO}_{x}, \mathrm{SO}_{2}$ concentrations, and VOC concentrations and speciation.

$\mathrm{NO}_{x}$, based on the estimate using the $\mathrm{NO}_{2}^{+} / \mathrm{NO}^{+}$ratios from AMS data. The significant contribution of organic nitrate to nitrate may have important implications for deriving the hygroscopicity from chemical composition. For example, a number of studies derived the hygroscopicity parameter by linear combination of the hygroscopicity parameters of various components such as sulfate, nitrate, and organics, assum- ing all nitrates are inorganic nitrate (Wu et al., 2013; Cubison et al., 2008; Yeung et al., 2014; Bhattu and Tripathi, 2015; Jaatinen et al., 2014; Moore et al., 2012; Gysel et al., 2007). Because the hygroscopicity parameter of organic nitrate may be much lower than inorganic nitrate (Suda et al., 2014), such derivation may overestimate hygroscopicity.

Organic nitrate compounds are estimated to contribute $7-$ $26 \%$ of the total organics using an average molecular weight of $200 \mathrm{~g} \mathrm{~mol}^{-1}$ for organic nitrate compounds and a higher contribution of organic nitrate was found at high $\mathrm{NO}_{x}$. Generally, SOA formed at high $\mathrm{NO}_{x}$ has a lower $\mathrm{H} / \mathrm{C}$ compared to that at low $\mathrm{NO}_{x}$. The higher contribution of organic nitrate to total organics and lower $\mathrm{H} / \mathrm{C}$ at high $\mathrm{NO}_{x}$ than at low $\mathrm{NO}_{x}$ is attributed to the reaction of $\mathrm{RO}_{2}$ with $\mathrm{NO}$, which produced more organic nitrates relative to organic hydroperoxides formed via the reaction of $\mathrm{RO}_{2}$ with $\mathrm{HO}_{2}$. The different chemical composition of SOA between high and low$\mathrm{NO}_{x}$ conditions may affect the physicochemical properties of SOA such as volatility, hygroscopicity, and optical properties and thus change the impact of SOA on environment and climate.

In this study, the influence of vapor wall loss on SOA yield was estimated, although the SOA yields in this study were not corrected for vapor wall loss. We need to be cautious about the enhancement of the SOA yield by $\mathrm{SO}_{2}$ under high- $\mathrm{NO}_{x}$ conditions and the suppression of the SOA yield by $\mathrm{NO}_{x}$ under low- $\mathrm{SO}_{2}$ conditions. These effects will be less pronounced when vapor wall loss is considered because of the significant vapor loss to chamber walls rather than to particles at low particle surface concentration. Yet, the low particle surface concentration and thus low condensational sink of vapors to particle surface reflect some real cases in the atmosphere, because when the condensational sink by particle surface is low in the atmosphere, organic vapors will be lost to the next largest sink, e.g., dry deposition. Nevertheless, our important findings hold for the influence of $\mathrm{NO}_{x}$ and $\mathrm{SO}_{2}$ on SOA new particle formation, mass yield, and chemical composition, showing indeed the interaction of anthropogenic and biogenic emissions in the process of SOA formation.

The different effects of $\mathrm{NO}_{x}$ and $\mathrm{SO}_{2}$ on new particle formation and SOA mass yields have important implications for SOA formation affected by anthropogenic-biogenic interactions in the ambient atmosphere. When an air mass of anthropogenic origin is transported to an area enriched in biogenic VOC emissions or vice versa, anthropogenic-biogenic interactions occur. Such scenarios are common in the ambient atmosphere in many areas. For example, Kiendler-Scharr et al. (2016) shows that the organic nitrate concentrations are high in all the rural sites all over Europe, indicating the important influence of anthropogenic emissions in rural areas which are often enriched in biogenic emissions. The ${ }^{14} \mathrm{C}$ analyses in several studies show that modern source carbon, from biogenic emission or biomass burning, accounts for large fractions of organic aerosol even in urban areas (Szidat 
et al., 2009; Weber et al., 2007; Sun et al., 2012), indicating the potential interactions of biogenic emissions with anthropogenic emissions in urban areas. In such cases, anthropogenic $\mathrm{NO}_{x}$ alone may suppress the new particle formation and SOA mass from biogenic VOC oxidation, as we found in this study, because in principle the suppression of SOA mass due to suppressed nucleation can occur in the ambient atmosphere, although chamber experiments often cannot accurately simulate the vapor loss on surface in the boundary layer. However, due to the coexistence of $\mathrm{NO}_{x}$ with $\mathrm{SO}_{2}$, $\mathrm{H}_{2} \mathrm{SO}_{4}$ formed by $\mathrm{SO}_{2}$ oxidation can counteract such suppression of particle mass because, regardless of $\mathrm{NO}_{x}$ levels, $\mathrm{H}_{2} \mathrm{SO}_{4}$ can induce new particle formation especially in the presence of water, ammonia, or amine (Berndt et al., 2005; Zhang et al., 2012; Sipila et al., 2010; Almeida et al., 2013; Kirkby et al., 2011; Chen et al., 2012). The overall effects on SOA mass depend on specific $\mathrm{NO}_{x}, \mathrm{SO}_{2}$, and VOC concentrations and VOC types as well as anthropogenic aerosol concentrations and can be a net suppressing, neutral, or enhancing effect. Such scheme is depicted in Fig. 8. Other anthropogenic emissions, such as primary anthropogenic aerosol and precursors of anthropogenic secondary aerosol, can have similar roles as $\mathrm{SO}_{2}$. By affecting the concentrations of $\mathrm{SO}_{2}$, $\mathrm{NO}_{x}$, and anthropogenic aerosol, anthropogenic emissions may have important mediating impacts on biogenic SOA formation. Considering the effects of these factors in isolation may cause bias in predicting biogenic SOA concentrations. The combined impacts of $\mathrm{SO}_{2}, \mathrm{NO}_{x}$, and anthropogenic aerosol are also important to the estimate on how much organic aerosol concentrations will change with the ongoing and future reduction of anthropogenic emissions (Carlton et al., 2010).

Data availability. All the data in the figures of this study are available upon request to the corresponding author (t.mentel@fzjuelich.de).

Supplement. The supplement related to this article is available online at: https://doi.org/10.5194/acp-18-1611-2018-supplement.

Competing interests. The authors declare that they have no conflict of interest.

Acknowledgements. We thank the SAPHIR team, especially Rolf Häseler, Florian Rubach, and Dieter Klemp, for supporting our measurements and providing helpful data. Mingjin Wang would like to thank the China Scholarship Council for funding the joint $\mathrm{PhD}$ program. We thank two anonymous reviewers for their helpful comments and suggestions.

The article processing charges for this open-access publication were covered by a Research
Centre of the Helmholtz Association.

Edited by: Hang Su

Reviewed by: two anonymous referees

\section{References}

Aiken, A. C., DeCarlo, P. F., and Jimenez, J. L.: Elemental analysis of organic species with electron ionization highresolution mass spectrometry, Anal. Chem., 79, 8350-8358, https://doi.org/10.1021/ac071150w, 2007.

Aiken, A. C., Decarlo, P. F., Kroll, J. H., Worsnop, D. R., Huffman, J. A., Docherty, K. S., Ulbrich, I. M., Mohr, C., Kimmel, J. R., Sueper, D., Sun, Y., Zhang, Q., Trimborn, A., Northway, M., Ziemann, P. J., Canagaratna, M. R., Onasch, T. B., Alfarra, M. R., Prevot, A. S. H., Dommen, J., Duplissy, J., Metzger, A., Baltensperger, U., and Jimenez, J. L.: $\mathrm{O} / \mathrm{C}$ and $\mathrm{OM} / \mathrm{OC}$ ratios of primary, secondary, and ambient organic aerosols with high-resolution time-of-flight aerosol mass spectrometry, Environ. Sci. Technol., 42, 4478-4485, https://doi.org/10.1021/es703009q, 2008.

Almeida, J., Schobesberger, S., Kurten, A., Ortega, I. K., Kupiainen-Maatta, O., Praplan, A. P., Adamov, A., Amorim, A., Bianchi, F., Breitenlechner, M., David, A., Dommen, J., Donahue, N. M., Downard, A., Dunne, E., Duplissy, J., Ehrhart, S., Flagan, R. C., Franchin, A., Guida, R., Hakala, J., Hansel, A., Heinritzi, M., Henschel, H., Jokinen, T., Junninen, H., Kajos, M., Kangasluoma, J., Keskinen, H., Kupc, A., Kurten, T., Kvashin, A. N., Laaksonen, A., Lehtipalo, K., Leiminger, M., Leppa, J., Loukonen, V., Makhmutov, V., Mathot, S., McGrath, M. J., Nieminen, T., Olenius, T., Onnela, A., Petaja, T., Riccobono, F., Riipinen, I., Rissanen, M., Rondo, L., Ruuskanen, T., Santos, F. D., Sarnela, N., Schallhart, S., Schnitzhofer, R., Seinfeld, J. H., Simon, M., Sipila, M., Stozhkov, Y., Stratmann, F., Tome, A., Trostl, J., Tsagkogeorgas, G., Vaattovaara, P., Viisanen, Y., Virtanen, A., Vrtala, A., Wagner, P. E., Weingartner, E., Wex, H., Williamson, C., Wimmer, D., Ye, P. L., Yli-Juuti, T., Carslaw, K. S., Kulmala, M., Curtius, J., Baltensperger, U., Worsnop, D. R., Vehkamaki, H., and Kirkby, J.: Molecular understanding of sulphuric acid-amine particle nucleation in the atmosphere, Nature, 502, 359-363, https://doi.org/10.1038/nature12663, 2013.

Atkinson, R. and Arey, J.: Atmospheric degradation of volatile organic compounds, Chem. Rev., 103, 4605-4638, https://doi.org/10.1021/cr0206420, 2003.

Atkinson, R., Baulch, D. L., Cox, R. A., Crowley, J. N., Hampson, R. F., Hynes, R. G., Jenkin, M. E., Rossi, M. J., and Troe, J.: Evaluated kinetic and photochemical data for atmospheric chemistry: Volume I - gas phase reactions of $\mathrm{O}_{\mathrm{x}}, \mathrm{HO}_{\mathrm{x}}$, $\mathrm{NO}_{\mathrm{x}}$ and $\mathrm{SO}_{\mathrm{x}}$ species, Atmos. Chem. Phys., 4, 1461-1738, https://doi.org/10.5194/acp-4-1461-2004, 2004.

Atkinson, R., Baulch, D. L., Cox, R. A., Crowley, J. N., Hampson, R. F., Hynes, R. G., Jenkin, M. E., Rossi, M. J., Troe, J., and IUPAC Subcommittee: Evaluated kinetic and photochemical data for atmospheric chemistry: Volume II - gas phase reactions of organic species, Atmos. Chem. Phys., 6, 3625-4055, https://doi.org/10.5194/acp-6-3625-2006, 2006.

Berndt, T., Boge, O., Stratmann, F., Heintzenberg, J., and Kulmala, M.: Rapid formation of sulfuric acid particles 
at near-atmospheric conditions, Science, 307, 698-700, https://doi.org/10.1126/science.1104054, 2005.

Berndt, T., Richters, S., Kaethner, R., Voigtlander, J., Stratmann, F., Sipila, M., Kulmala, M., and Herrmann, H.: Gas-Phase Ozonolysis of Cycloalkenes: Formation of Highly Oxidized $\mathrm{RO}_{2}$ Radicals and Their Reactions with $\mathrm{NO}, \mathrm{NO}_{2}, \mathrm{SO}_{2}$, and Other $\mathrm{RO}_{2}$ Radicals, J. Phys. Chem. A, 119, 10336-10348, https://doi.org/10.1021/acs.jpca.5b07295, 2015.

Bhattu, D. and Tripathi, S. N.: CCN closure study: Effects of aerosol chemical composition and mixing state, J. Geophys. Res.Atmos., 120, 766-783, https://doi.org/10.1002/2014jd021978, 2015.

Bohn, B. and Zilken, H.: Model-aided radiometric determination of photolysis frequencies in a sunlit atmosphere simulation chamber, Atmos. Chem. Phys., 5, 191-206, https://doi.org/10.5194/acp-5-191-2005, 2005.

Bohn, B., Rohrer, F., Brauers, T., and Wahner, A.: Actinometric measurements of $\mathrm{NO}_{2}$ photolysis frequencies in the atmosphere simulation chamber SAPHIR, Atmos. Chem. Phys., 5, 493-503, https://doi.org/10.5194/acp-5-493-2005, 2005.

Canagaratna, M. R., Jimenez, J. L., Kroll, J. H., Chen, Q., Kessler, S. H., Massoli, P., Hildebrandt Ruiz, L., Fortner, E., Williams, L. R., Wilson, K. R., Surratt, J. D., Donahue, N. M., Jayne, J. T., and Worsnop, D. R.: Elemental ratio measurements of organic compounds using aerosol mass spectrometry: characterization, improved calibration, and implications, Atmos. Chem. Phys., 15, 253-272, https://doi.org/10.5194/acp-15-253-2015, 2015.

Carlton, A. G., Wiedinmyer, C., and Kroll, J. H.: A review of Secondary Organic Aerosol (SOA) formation from isoprene, Atmos. Chem. Phys., 9, 4987-5005, https://doi.org/10.5194/acp-9-49872009, 2009.

Carlton, A. G., Pinder, R. W., Bhave, P. V., and Pouliot, G. A.: To What Extent Can Biogenic SOA be Controlled?, Environ. Sci. Technol., 44, 3376-3380, https://doi.org/10.1021/es903506b, 2010.

Chen, M., Titcombe, M., Jiang, J. K., Jen, C., Kuang, C. A., Fischer, M. L., Eisele, F. L., Siepmann, J. I., Hanson, D. R., Zhao, J., and McMurry, P. H.: Acid-base chemical reaction model for nucleation rates in the polluted atmospheric boundary layer, P. Natl. Acad. Sci. USA, 109, 18713-18718, https://doi.org/10.1073/pnas.1210285109, 2012.

Chhabra, P. S., Ng, N. L., Canagaratna, M. R., Corrigan, A. L., Russell, L. M., Worsnop, D. R., Flagan, R. C., and Seinfeld, J. H.: Elemental composition and oxidation of chamber organic aerosol, Atmos. Chem. Phys., 11, 8827-8845, https://doi.org/10.5194/acp-11-8827-2011, 2011.

Chu, B., Zhang, X., Liu, Y., He, H., Sun, Y., Jiang, J., Li, J., and Hao, J.: Synergetic formation of secondary inorganic and organic aerosol: effect of $\mathrm{SO}_{2}$ and $\mathrm{NH}_{3}$ on particle formation and growth, Atmos. Chem. Phys., 16, 14219-14230, https://doi.org/10.5194/acp-16-14219-2016, 2016.

Chung, S. H. and Seinfeld, J. H.: Global distribution and climate forcing of carbonaceous aerosols, J. Geophys. Res.-Atmos., 107, 4407, https://doi.org/10.1029/2001jd001397, 2002.

Clegg, S. L., Brimblecombe, P., and Wexler, A. S.: Thermodynamic model of the system $\mathrm{H}^{+}-\mathrm{NH}_{4}^{+}-\mathrm{SO}_{4}^{2-}-\mathrm{NO}_{3}^{-}-\mathrm{H}_{2} \mathrm{O}$ at tropospheric temperatures, J. Phys. Chem. A 102, 2137-2154, https://doi.org/10.1021/jp973042r, 1998.
Cubison, M. J., Ervens, B., Feingold, G., Docherty, K. S., Ulbrich, I. M., Shields, L., Prather, K., Hering, S., and Jimenez, J. L.: The influence of chemical composition and mixing state of Los Angeles urban aerosol on CCN number and cloud properties, Atmos. Chem. Phys., 8, 5649-5667, https://doi.org/10.5194/acp-8-56492008, 2008.

de Gouw, J. A., Middlebrook, A. M., Warneke, C., Goldan, P. D., Kuster, W. C., Roberts, J. M., Fehsenfeld, F. C., Worsnop, D. R., Canagaratna, M. R., Pszenny, A. A. P., Keene, W. C., Marchewka, M., Bertman, S. B., and Bates, T. S.: Budget of organic carbon in a polluted atmosphere: Results from the New England Air Quality Study in 2002, J. Geophys. Res.-Atmos., 110, D16305, https://doi.org/10.1029/2004jd005623, 2005.

Ding, X. A., Wang, X. M., and Zheng, M.: The influence of temperature and aerosol acidity on biogenic secondary organic aerosol tracers: Observations at a rural site in the central Pearl River Delta region, South China, Atmos. Environ., 45, 1303-1311, https://doi.org/10.1016/j.atmosenv.2010.11.057, 2011.

Draper, D. C., Farmer, D. K., Desyaterik, Y., and Fry, J. L.: A qualitative comparison of secondary organic aerosol yields and composition from ozonolysis of monoterpenes at varying concentrations of $\mathrm{NO}_{2}$, Atmos. Chem. Phys., 15, 12267-12281, https://doi.org/10.5194/acp-15-12267-2015, 2015.

Eddingsaas, N. C., Loza, C. L., Yee, L. D., Chan, M., Schilling, K. A., Chhabra, P. S., Seinfeld, J. H., and Wennberg, P. O.: $\alpha$-pinene photooxidation under controlled chemical conditions - Part 2: SOA yield and composition in low- and high- $\mathrm{NO}_{\mathrm{x}}$ environments, Atmos. Chem. Phys., 12, 7413-7427, https://doi.org/10.5194/acp-12-7413-2012, 2012a.

Eddingsaas, N. C., Loza, C. L., Yee, L. D., Seinfeld, J. H., and Wennberg, P. O.: $\alpha$-pinene photooxidation under controlled chemical conditions - Part 1: Gas-phase composition in low- and high- $\mathrm{NO}_{\mathrm{x}}$ environments, Atmos. Chem. Phys., 12, 6489-6504, https://doi.org/10.5194/acp-12-6489-2012, 2012b.

Ehn, M., Thornton, J. A., Kleist, E., Sipila, M., Junninen, H., Pullinen, I., Springer, M., Rubach, F., Tillmann, R., Lee, B., Lopez-Hilfiker, F., Andres, S., Acir, I. H., Rissanen, M., Jokinen, T., Schobesberger, S., Kangasluoma, J., Kontkanen, J., Nieminen, T., Kurten, T., Nielsen, L. B., Jorgensen, S., Kjaergaard, H. G., Canagaratna, M., Dal Maso, M., Berndt, T., Petaja, T., Wahner, A., Kerminen, V. M., Kulmala, M., Worsnop, D. R., Wildt, J., and Mentel, T. F.: A large source of lowvolatility secondary organic aerosol, Nature, 506, 476-479, https://doi.org/10.1038/nature13032, 2014.

Emanuelsson, E. U., Hallquist, M., Kristensen, K., Glasius, M., Bohn, B., Fuchs, H., Kammer, B., Kiendler-Scharr, A., Nehr, S., Rubach, F., Tillmann, R., Wahner, A., Wu, H.-C., and Mentel, Th. F.: Formation of anthropogenic secondary organic aerosol (SOA) and its influence on biogenic SOA properties, Atmos. Chem. Phys., 13, 2837-2855, https://doi.org/10.5194/acp-132837-2013, 2013.

Farmer, D. K., Matsunaga, A., Docherty, K. S., Surratt, J. D., Seinfeld, J. H., Ziemann, P. J., and Jimenez, J. L.: Response of an aerosol mass spectrometer to organonitrates and organosulfates and implications for atmospheric chemistry, P. Natl. Acad. Sci. USA, 107, 6670-6675, https://doi.org/10.1073/pnas.0912340107, 2010. 
Finlayson-Pitts, B. J., and Pitts Jr., J. N.: Chemistry of the upper and lower atmosphere: theory, experiments, and applications, Academic Press, San Diego, 969 pp., 1999.

Flores, J. M., Zhao, D. F., Segev, L., Schlag, P., KiendlerScharr, A., Fuchs, H., Watne, ̊. K., Bluvshtein, N., Mentel, Th. F., Hallquist, M., and Rudich, Y.: Evolution of the complex refractive index in the UV spectral region in ageing secondary organic aerosol, Atmos. Chem. Phys., 14, 5793-5806, https://doi.org/10.5194/acp-14-5793-2014, 2014.

Friedman, B., Brophy, P., Brune, W. H., and Farmer, D. K.: Anthropogenic Sulfur Perturbations on Biogenic Oxidation: SO2 Additions Impact Gas-Phase OH Oxidation Products of alpha- and beta-Pinene, Environ. Sci. Technol., 50, 1269-1279, https://doi.org/10.1021/acs.est.5b05010, 2016.

Fry, J. L., Kiendler-Scharr, A., Rollins, A. W., Wooldridge, P. J., Brown, S. S., Fuchs, H., Dubé, W., Mensah, A., dal Maso, M., Tillmann, R., Dorn, H.-P., Brauers, T., and Cohen, R. C.: Organic nitrate and secondary organic aerosol yield from $\mathrm{NO}_{3}$ oxidation of $\beta$-pinene evaluated using a gas-phase kinetics/aerosol partitioning model, Atmos. Chem. Phys., 9, 14311449, https://doi.org/10.5194/acp-9-1431-2009, 2009.

Fuchs, H., Dorn, H.-P., Bachner, M., Bohn, B., Brauers, T., Gomm, S., Hofzumahaus, A., Holland, F., Nehr, S., Rohrer, F., Tillmann, R., and Wahner, A.: Comparison of $\mathrm{OH}$ concentration measurements by DOAS and LIF during SAPHIR chamber experiments at high $\mathrm{OH}$ reactivity and low NO concentration, Atmos. Meas. Tech., 5, 1611-1626, https://doi.org/10.5194/amt-5-1611-2012, 2012.

Glasius, M., la Cour, A., and Lohse, C.: Fossil and nonfossil carbon in fine particulate matter: A study of five European cities, J. Geophys. Res.-Atmos., 116, D11302, https://doi.org/10.1029/2011jd015646, 2011

Goldstein, A. H., Koven, C. D., Heald, C. L., and Fung, I. Y.: Biogenic carbon and anthropogenic pollutants combine to form a cooling haze over the southeastern United States, P. Natl. Acad. Sci. USA, 106, 8835-8840, https://doi.org/10.1073/pnas.0904128106, 2009.

Griffin, R. J., Cocker, D. R., Flagan, R. C., and Seinfeld, J. H.: Organic aerosol formation from the oxidation of biogenic hydrocarbons, J. Geophys. Res.-Atmos., 104, 3555-3567, https://doi.org/10.1029/1998jd100049, 1999.

Guenther, A., Hewitt, C. N., Erickson, D., Fall, R., Geron, C., Graedel, T., Harley, P., Klinger, L., Lerdau, M., McKay, W. A., Pierce, T., Scholes, B., Steinbrecher, R., Tallamraju, R., Taylor, J., and Zimmerman, P.: A global-model of natural volatile organic-compound emissions, J. Geophys. Res.-Atmos., 100, 8873-8892, https://doi.org/10.1029/94jd02950, 1995.

Guenther, A. B., Jiang, X., Heald, C. L., Sakulyanontvittaya, T., Duhl, T., Emmons, L. K., and Wang, X.: The Model of Emissions of Gases and Aerosols from Nature version 2.1 (MEGAN2.1): an extended and updated framework for modeling biogenic emissions, Geosci. Model Dev., 5, 1471-1492, https://doi.org/10.5194/gmd-5-1471-2012, 2012.

Gysel, M., Crosier, J., Topping, D. O., Whitehead, J. D., Bower, K. N., Cubison, M. J., Williams, P. I., Flynn, M. J., McFiggans, G. B., and Coe, H.: Closure study between chemical composition and hygroscopic growth of aerosol particles during TORCH2, Atmos. Chem. Phys., 7, 6131-6144, https://doi.org/10.5194/acp7-6131-2007, 2007.
Hallquist, M., Wenger, J. C., Baltensperger, U., Rudich, Y., Simpson, D., Claeys, M., Dommen, J., Donahue, N. M., George, C., Goldstein, A. H., Hamilton, J. F., Herrmann, H., Hoffmann, T., Iinuma, Y., Jang, M., Jenkin, M. E., Jimenez, J. L., Kiendler-Scharr, A., Maenhaut, W., McFiggans, G., Mentel, Th. F., Monod, A., Prévôt, A. S. H., Seinfeld, J. H., Surratt, J. D., Szmigielski, R., and Wildt, J.: The formation, properties and impact of secondary organic aerosol: current and emerging issues, Atmos. Chem. Phys., 9, 5155-5236, https://doi.org/10.5194/acp9-5155-2009, 2009.

Han, Y., Stroud, C. A., Liggio, J., and Li, S.-M.: The effect of particle acidity on secondary organic aerosol formation from $\alpha$-pinene photooxidation under atmospherically relevant conditions, Atmos. Chem. Phys., 16, 13929-13944, https://doi.org/10.5194/acp-16-13929-2016, 2016.

Hatakeyama, S., Izumi, K., Fukuyama, T., Akimoto, H., and Washida, N.: Reactions of oh with alpha-pinene and beta-pinene in air - estimate of global co production from the atmospheric oxidation of terpenes, J. Geophys. Res.-Atmos., 96, 947-958, https://doi.org/10.1029/90jd02341, 1991.

Henry, K. M., Lohaus, T., and Donahue, N. M.: Organic Aerosol Yields from alpha-Pinene Oxidation: Bridging the Gap between First-Generation Yields and Aging Chemistry, Environ. Sci. Technol., 46, 12347-12354, https://doi.org/10.1021/es302060y, 2012.

Hoffmann, T., Odum, J. R., Bowman, F., Collins, D., Klockow, D., Flagan, R. C., and Seinfeld, J. H.: Formation of organic aerosols from the oxidation of biogenic hydrocarbons, J. Atmos. Chem., 26, 189-222, https://doi.org/10.1023/a:1005734301837, 1997.

Hoyle, C. R., Boy, M., Donahue, N. M., Fry, J. L., Glasius, M., Guenther, A., Hallar, A. G., Huff Hartz, K., Petters, M. D., Petäjä, T., Rosenoern, T., and Sullivan, A. P.: A review of the anthropogenic influence on biogenic secondary organic aerosol, Atmos. Chem. Phys., 11, 321-343, https://doi.org/10.5194/acp-11-3212011, 2011.

Iinuma, Y., Boege, O., Kahnt, A., and Herrmann, H.: Laboratory chamber studies on the formation of organosulfates from reactive uptake of monoterpene oxides, Phys. Chem. Chem. Phys., 11, 7985-7997, https://doi.org/10.1039/b904025k, 2009.

Jaatinen, A., Romakkaniemi, S., Anttila, T., Hyvarinen, A. P., Hao, L. Q., Kortelainen, A., Miettinen, P., Mikkonen, S., Smith, J. N., Virtanen, A., and Laaksonen, A.: The third Pallas Cloud Experiment: Consistency between the aerosol hygroscopic growth and CCN activity, Boreal Environ. Res., 19, 368-382, 2014.

Jang, M. S., Czoschke, N. M., Lee, S., and Kamens, R. M.: Heterogeneous atmospheric aerosol production by acid-catalyzed particle-phase reactions, Science, 298, 814-817, 10.1126/science.1075798, 2002.

Jenkin, M. E., Saunders, S. M., and Pilling, M. J.: The tropospheric degradation of volatile organic compounds: A protocol for mechanism development, Atmos. Environ., 31, 81-104, https://doi.org/10.1016/s1352-2310(96)00105-7, 1997.

Jimenez, J. L., Canagaratna, M. R., Donahue, N. M., Prevot, A. S. H., Zhang, Q., Kroll, J. H., DeCarlo, P. F., Allan, J. D., Coe, H., Ng, N. L., Aiken, A. C., Docherty, K. S., Ulbrich, I. M., Grieshop, A. P., Robinson, A. L., Duplissy, J., Smith, J. D., Wilson, K. R., Lanz, V. A., Hueglin, C., Sun, Y. L., Tian, J., Laaksonen, A., Raatikainen, T., Rautiainen, J., Vaattovaara, P., Ehn, M., Kulmala, M., Tomlinson, J. M., Collins, D. R., Cubison, M. 
J., Dunlea, E. J., Huffman, J. A., Onasch, T. B., Alfarra, M. R., Williams, P. I., Bower, K., Kondo, Y., Schneider, J., Drewnick, F., Borrmann, S., Weimer, S., Demerjian, K., Salcedo, D., Cottrell, L., Griffin, R., Takami, A., Miyoshi, T., Hatakeyama, S., Shimono, A., Sun, J. Y., Zhang, Y. M., Dzepina, K., Kimmel, J. R., Sueper, D., Jayne, J. T., Herndon, S. C., Trimborn, A. M., Williams, L. R., Wood, E. C., Middlebrook, A. M., Kolb, C. E., Baltensperger, U., and Worsnop, D. R.: Evolution of Organic Aerosols in the Atmosphere, Science, 326, 1525-1529, https://doi.org/10.1126/science.1180353, 2009.

Kanakidou, M., Seinfeld, J. H., Pandis, S. N., Barnes, I., Dentener, F. J., Facchini, M. C., Van Dingenen, R., Ervens, B., Nenes, A., Nielsen, C. J., Swietlicki, E., Putaud, J. P., Balkanski, Y., Fuzzi, S., Horth, J., Moortgat, G. K., Winterhalter, R., Myhre, C. E. L., Tsigaridis, K., Vignati, E., Stephanou, E. G., and Wilson, J.: Organic aerosol and global climate modelling: a review, Atmos. Chem. Phys., 5, 1053-1123, https://doi.org/10.5194/acp-5-10532005, 2005.

Kiendler-Scharr, A., Mensah, A. A., Friese, E., Topping, D., Nemitz, E., Prevot, A. S. H., Äijälä, M., Allan, J., Canonaco, F., Canagaratna, M., Carbone, S., Crippa, M., Dall Osto, M., Day, D. A., De Carlo, P., Di Marco, C. F., Elbern, H., Eriksson, A., Freney, E., Hao, L., Herrmann, H., Hildebrandt, L., Hillamo, R., Jimenez, J. L., Laaksonen, A., McFiggans, G., Mohr, C., O'Dowd, C., Otjes, R., Ovadnevaite, J., Pandis, S. N., Poulain, L., Schlag, P., Sellegri, K., Swietlicki, E., Tiitta, P., Vermeulen, A., Wahner, A., Worsnop, D., and Wu, H. C.: Ubiquity of organic nitrates from nighttime chemistry in the European submicron aerosol, Geophys. Res. Lett., 43, 7735-7744, https://doi.org/10.1002/2016GL069239, 2016.

Kirkby, J., Curtius, J., Almeida, J., Dunne, E., Duplissy, J., Ehrhart, S., Franchin, A., Gagne, S., Ickes, L., Kurten, A., Kupc, A., Metzger, A., Riccobono, F., Rondo, L., Schobesberger, S., Tsagkogeorgas, G., Wimmer, D., Amorim, A., Bianchi, F., Breitenlechner, M., David, A., Dommen, J., Downard, A., Ehn, M., Flagan, R. C., Haider, S., Hansel, A., Hauser, D., Jud, W., Junninen, H., Kreissl, F., Kvashin, A., Laaksonen, A., Lehtipalo, K., Lima, J., Lovejoy, E. R., Makhmutov, V., Mathot, S., Mikkila, J., Minginette, P., Mogo, S., Nieminen, T., Onnela, A., Pereira, P., Petaja, T., Schnitzhofer, R., Seinfeld, J. H., Sipila, M., Stozhkov, Y., Stratmann, F., Tome, A., Vanhanen, J., Viisanen, Y., Vrtala, A., Wagner, P. E., Walther, H., Weingartner, E., Wex, H., Winkler, P. M., Carslaw, K. S., Worsnop, D. R., Baltensperger, U., and Kulmala, M.: Role of sulphuric acid, ammonia and galactic cosmic rays in atmospheric aerosol nucleation, Nature, 476, 429-477, https://doi.org/10.1038/nature10343, 2011.

Kirkby, J., Duplissy, J., Sengupta, K., Frege, C., Gordon, H., Williamson, C., Heinritzi, M., Simon, M., Yan, C., Almeida, J., Tröstl, J., Nieminen, T., Ortega, I. K., Wagner, R., Adamov, A., Amorim, A., Bernhammer, A.-K., Bianchi, F., Breitenlechner, M., Brilke, S., Chen, X., Craven, J., Dias, A., Ehrhart, S., Flagan, R. C., Franchin, A., Fuchs, C., Guida, R., Hakala, J., Hoyle, C. R., Jokinen, T., Junninen, H., Kangasluoma, J., Kim, J., Krapf, M., Kürten, A., Laaksonen, A., Lehtipalo, K., Makhmutov, V., Mathot, S., Molteni, U., Onnela, A., Peräkylä, O., Piel, F., Petäjä, T., Praplan, A. P., Pringle, K., Rap, A., Richards, N. A. D., Riipinen, I., Rissanen, M. P., Rondo, L., Sarnela, N., Schobesberger, S., Scott, C. E., Seinfeld, J. H., Sipilä, M., Steiner, G., Stozhkov, Y., Stratmann, F., Tomé, A., Virtanen, A., Vogel, A. L., Wag- ner, A. C., Wagner, P. E., Weingartner, E., Wimmer, D., Winkler, P. M., Ye, P., Zhang, X., Hansel, A., Dommen, J., Donahue, N. M., Worsnop, D. R., Baltensperger, U., Kulmala, M., Carslaw, K. S., and Curtius, J.: Ion-induced nucleation of pure biogenic particles, Nature, 533, 521-526, https://doi.org/10.1038/nature17953, 2016.

Kleindienst, T. E., Edney, E. O., Lewandowski, M., Offenberg, J. H., and Jaoui, M.: Secondary organic carbon and aerosol yields from the irradiations of isoprene and alpha-pinene in the presence of $\mathrm{NO}_{x}$ and $\mathrm{SO}_{2}$, Environ. Sci. Technol., 40, 3807-3812, https://doi.org/10.1021/es052446r, 2006.

Krechmer, J. E., Pagonis, D., Ziemann, P. J., and Jimenez, J. L.: Quantification of Gas-Wall Partitioning in Teflon Environmental Chambers Using Rapid Bursts of Low-Volatility Oxidized Species Generated in Situ, Environ. Sci. Technol., 50, 57575765, https://doi.org/10.1021/acs.est.6b00606, 2016.

Kroll, J. H., Ng, N. L., Murphy, S. M., Flagan, R. C., and Seinfeld, J. H.: Secondary organic aerosol formation from isoprene photooxidation, Environ. Sci. Technol., 40, 1869-1877, https://doi.org/10.1021/es0524301, 2006.

Kroll, J. H., Chan, A. W. H., Ng, N. L., Flagan, R. C., and Seinfeld, J. H.: Reactions of semivolatile organics and their effects on secondary organic aerosol formation, Environ. Sci. Technol., 41, 3545-3550, https://doi.org/10.1021/es062059x, 2007.

Lal, V., Khalizov, A. F., Lin, Y., Galvan, M. D., Connell, B. T., and Zhang, R. Y.: Heterogeneous Reactions of Epoxides in Acidic Media, J. Phys. Chem. A 116, 6078-6090, https://doi.org/10.1021/jp2112704, 2012.

Lee, B. H., Mohr, C., Lopez-Hilfiker, F. D., Lutz, A., Hallquist, M., Lee, L., Romer, P., Cohen, R. C., Iyer, S., Kurten, T., Hu, W., Day, D. A., Campuzano-Jost, P., Jimenez, J. L., Xu, L., Ng, N. L., Guo, H., Weber, R. J., Wild, R. J., Brown, S. S., Koss, A., de Gouw, J., Olson, K., Goldstein, A. H., Seco, R., Kim, S., McAvey, K., Shepson, P. B., Starn, T., Baumann, K., Edgerton, E. S., Liu, J., Shilling, J. E., Miller, D. O., Brune, W., Schobesberger, S., D'Ambro, E. L., and Thornton, J. A.: Highly functionalized organic nitrates in the southeast United States: Contribution to secondary organic aerosol and reactive nitrogen budgets, P. Natl. Acad. Sci. USA, 113, 1516-1521, https://doi.org/10.1073/pnas.1508108113, 2016.

Lightfoot, P. D., Cox, R. A., Crowley, J. N., Destriau, M., Hayman, G. D., Jenkin, M. E., Moortgat, G. K., and Zabel, F.: Organic peroxy-radicals - kinetics, spectroscopy and tropospheric chemistry, Atmos. Environ. A-Gen., 26, 1805-1961, https://doi.org/10.1016/0960-1686(92)90423-i, 1992.

Lin, Y. H., Zhang, Z. F., Docherty, K. S., Zhang, H. F., Budisulistiorini, S. H., Rubitschun, C. L., Shaw, S. L., Knipping, E. M., Edgerton, E. S., Kleindienst, T. E., Gold, A., and Surratt, J. D.: Isoprene Epoxydiols as Precursors to Secondary Organic Aerosol Formation: Acid-Catalyzed Reactive Uptake Studies with Authentic Compounds, Environ. Sci. Technol., 46, 250258, https://doi.org/10.1021/es202554c, 2012.

Liu, T., Wang, X., Hu, Q., Deng, W., Zhang, Y., Ding, X., Fu, X., Bernard, F., Zhang, Z., Lü, S., He, Q., Bi, X., Chen, J., Sun, Y., Yu, J., Peng, P., Sheng, G., and Fu, J.: Formation of secondary aerosols from gasoline vehicle exhaust when mixing with $\mathrm{SO}_{2}$, Atmos. Chem. Phys., 16, 675-689, https://doi.org/10.5194/acp16-675-2016, 2016. 
Loza, C. L., Chan, A. W. H., Galloway, M. M., Keutsch, F. N., Flagan, R. C., and Seinfeld, J. H.: Characterization of Vapor Wall Loss in Laboratory Chambers, Environ. Sci. Technol., 44, 50745078, https://doi.org/10.1021/es100727v, 2010.

Matsunaga, A. and Ziemann, P. J.: Gas-Wall Partitioning of Organic Compounds in a Teflon Film Chamber and Potential Effects on Reaction Product and Aerosol Yield Measurements, Aerosol Sci. Technol., 44, 881-892, https://doi.org/10.1080/02786826.2010.501044, 2010.

McVay, R. C., Zhang, X., Aumont, B., Valorso, R., Camredon, M., La, Y. S., Wennberg, P. O., and Seinfeld, J. H.: SOA formation from the photooxidation of a-pinene: systematic exploration of the simulation of chamber data, Atmos. Chem. Phys., 16, 27852802, https://doi.org/10.5194/acp-16-2785-2016, 2016.

Moore, R. H., Cerully, K., Bahreini, R., Brock, C. A., Middlebrook, A. M., and Nenes, A.: Hygroscopicity and composition of California CCN during summer 2010, J. Geophys. Res.-Atmos., 117, D00v12, https://doi.org/10.1029/2011jd017352, 2012.

Nah, T., McVay, R. C., Zhang, X., Boyd, C. M., Seinfeld, J. H., and $\mathrm{Ng}, \mathrm{N}$. L.: Influence of seed aerosol surface area and oxidation rate on vapor wall deposition and SOA mass yields: a case study with $\alpha$-pinene ozonolysis, Atmos. Chem. Phys., 16, 9361-9379, https://doi.org/10.5194/acp-16-9361-2016, 2016.

Ng, N. L., Chhabra, P. S., Chan, A. W. H., Surratt, J. D., Kroll, J. H., Kwan, A. J., McCabe, D. C., Wennberg, P. O., Sorooshian, A., Murphy, S. M., Dalleska, N. F., Flagan, R. C., and Seinfeld, J. H.: Effect of $\mathrm{NO}_{\mathrm{x}}$ level on secondary organic aerosol (SOA) formation from the photooxidation of terpenes, Atmos. Chem. Phys., 7, 5159-5174, https://doi.org/10.5194/acp-7-5159-2007, 2007.

Ng, N. L., Canagaratna, M. R., Jimenez, J. L., Chhabra, P. S., Seinfeld, J. H., and Worsnop, D. R.: Changes in organic aerosol composition with aging inferred from aerosol mass spectra, Atmos. Chem. Phys., 11, 6465-6474, https://doi.org/10.5194/acp11-6465-2011, 2011.

Northcross, A. L. and Jang, M.: Heterogeneous SOA yield from ozonolysis of monoterpenes in the presence of inorganic acid, Atmos. Environ., 41, 1483-1493, https://doi.org/10.1016/j.atmosenv.2006.10.009, 2007.

Offenberg, J. H., Lewandowski, M., Edney, E. O., Kleindienst, T. E., and Jaoui, M.: Influence of Aerosol Acidity on the Formation of Secondary Organic Aerosol from Biogenic Precursor Hydrocarbons, Environ. Sci. Technol., 43, 7742-7747, https://doi.org/10.1021/es901538e, 2009.

Pandis, S. N., Paulson, S. E., Seinfeld, J. H., and Flagan, R. C.: Aerosol formation in the photooxidation of isoprene and beta-pinene, Atmos. Environ. A-Gen., 25, 997-1008, https://doi.org/10.1016/0960-1686(91)90141-s, 1991.

Presto, A. A., Hartz, K. E. H., and Donahue, N. M.: Secondary organic aerosol production from terpene ozonolysis. 2. Effect of NOx concentration, Environ. Sci. Technol., 39, 7046-7054, https://doi.org/10.1021/es050400s, 2005.

Pullinen, I., Schmitt, S., Sarrafzadeh, M., Kang, S., Schlag, P., Andres, S., Kleist, E., Mentel, T. F., Rohrer, F., Springer, M., Tillmann, R., Wildt, J., Wu, C., Zhao, D., Wahner, A., and KiendlerScharr, A.: Impact of NOx on secondary organic aerosol (SOA) formation from $\alpha$-pinene and $\beta$-pinene photo-oxidation: the role of organic nitrates, Atmos. Chem. Phys., in preparation, 2018.

Rohrer, F., Bohn, B., Brauers, T., Brüning, D., Johnen, F.-J., Wahner, A., and Kleffmann, J.: Characterisation of the photolytic
HONO-source in the atmosphere simulation chamber SAPHIR, Atmos. Chem. Phys., 5, 2189-2201, https://doi.org/10.5194/acp5-2189-2005, 2005.

Rollins, A. W., Kiendler-Scharr, A., Fry, J. L., Brauers, T., Brown, S. S., Dorn, H.-P., Dubé, W. P., Fuchs, H., Mensah, A., Mentel, T. F., Rohrer, F., Tillmann, R., Wegener, R., Wooldridge, P. J., and Cohen, R. C.: Isoprene oxidation by nitrate radical: alkyl nitrate and secondary organic aerosol yields, Atmos. Chem. Phys., 9, 6685-6703, https://doi.org/10.5194/acp-9-6685-2009, 2009.

Sarrafzadeh, M., Wildt, J., Pullinen, I., Springer, M., Kleist, E., Tillmann, R., Schmitt, S. H., Wu, C., Mentel, T. F., Zhao, D., Hastie, D. R., and Kiendler-Scharr, A.: Impact of $\mathrm{NO}_{x}$ and $\mathrm{OH}$ on secondary organic aerosol formation from $\beta$ pinene photooxidation, Atmos. Chem. Phys., 16, 11237-11248, https://doi.org/10.5194/acp-16-11237-2016, 2016.

Saunders, S. M., Jenkin, M. E., Derwent, R. G., and Pilling, M. J.: Protocol for the development of the Master Chemical Mechanism, MCM v3 (Part A): tropospheric degradation of nonaromatic volatile organic compounds, Atmos. Chem. Phys., 3, 161-180, https://doi.org/10.5194/acp-3-161-2003, 2003.

Shilling, J. E., Zaveri, R. A., Fast, J. D., Kleinman, L., Alexander, M. L., Canagaratna, M. R., Fortner, E., Hubbe, J. M., Jayne, J. T., Sedlacek, A., Setyan, A., Springston, S., Worsnop, D. R., and Zhang, Q.: Enhanced SOA formation from mixed anthropogenic and biogenic emissions during the CARES campaign, Atmos. Chem. Phys., 13, 2091-2113, https://doi.org/10.5194/acp-132091-2013, 2013.

Sipila, M., Berndt, T., Petaja, T., Brus, D., Vanhanen, J., Stratmann, F., Patokoski, J., Mauldin, R. L., Hyvarinen, A. P., Lihavainen, H., and Kulmala, M.: The Role of Sulfuric Acid in Atmospheric Nucleation, Science, 327, 1243-1246, https://doi.org/10.1126/science.1180315, 2010.

Spracklen, D. V., Jimenez, J. L., Carslaw, K. S., Worsnop, D. R., Evans, M. J., Mann, G. W., Zhang, Q., Canagaratna, M. R., Allan, J., Coe, H., McFiggans, G., Rap, A., and Forster, P.: Aerosol mass spectrometer constraint on the global secondary organic aerosol budget, Atmos. Chem. Phys., 11, 12109-12136, https://doi.org/10.5194/acp-11-12109-2011, 2011.

Stirnweis, L., Marcolli, C., Dommen, J., Barmet, P., Frege, C., Platt, S. M., Bruns, E. A., Krapf, M., Slowik, J. G., Wolf, R., Prévôt, A. S. H., Baltensperger, U., and El-Haddad, I.: Assessing the influence of $\mathrm{NO}_{x}$ concentrations and relative humidity on secondary organic aerosol yields from $\alpha$-pinene photo-oxidation through smog chamber experiments and modelling calculations, Atmos. Chem. Phys., 17, 5035-5061, https://doi.org/10.5194/acp-175035-2017, 2017.

Suda, S. R., Petters, M. D., Yeh, G. K., Strollo, C., Matsunaga, A., Faulhaber, A., Ziemann, P. J., Prenni, A. J., Carrico, C. M., Sullivan, R. C., and Kreidenweis, S. M.: Influence of Functional Groups on Organic Aerosol Cloud Condensation Nucleus Activity, Environ. Sci. Technol., 48, 10182-10190, https://doi.org/10.1021/es502147y, 2014.

Sun, X. S., Hu, M., Guo, S., Liu, K. X., and Zhou, L. P.: C-14-Based source assessment of carbonaceous aerosols at a rural site, Atmos. Environ., 50, 36-40, https://doi.org/10.1016/j.atmosenv.2012.01.008, 2012.

Surratt, J. D., Lewandowski, M., Offenberg, J. H., Jaoui, M., Kleindienst, T. E., Edney, E. O., and Seinfeld, J. H.: Effect of acidity on secondary organic aerosol formation from isoprene, Environ. Sci. 
Technol., 41, 5363-5369, https://doi.org/10.1021/es0704176, 2007.

Szidat, S., Ruff, M., Perron, N., Wacker, L., Synal, H.-A., Hallquist, M., Shannigrahi, A. S., Yttri, K. E., Dye, C., and Simpson, D.: Fossil and non-fossil sources of organic carbon (OC) and elemental carbon (EC) in Göteborg, Sweden, Atmos. Chem. Phys., 9, 1521-1535, https://doi.org/10.5194/acp-9-1521-2009, 2009.

Wang, T. H., Liu, Z., Wang, W. G., and Ge, M. F.: Heterogeneous Uptake Kinetics of Limonene and Limonene Oxide by Sulfuric Acid Solutions, Acta Phys. Chim. Sin. , 28, 1608-1614, https://doi.org/10.3866/pku.whxb201204241, 2012.

Weber, R. J., Sullivan, A. P., Peltier, R. E., Russell, A., Yan, B., Zheng, M., de Gouw, J., Warneke, C., Brock, C., Holloway, J. S., Atlas, E. L., and Edgerton, E.: A study of secondary organic aerosol formation in the anthropogenic-influenced southeastern United States, J. Geophys. Res.-Atmos., 112, D13302, https://doi.org/10.1029/2007jd008408, 2007.

Wennberg, P. O.: Let's abandon the "high NOx" and "low NOx" terminology, IGAC News, 3-4, 2013.

Wexler, A. S. and Clegg, S. L.: Atmospheric aerosol models for systems including the ions $\mathrm{H}+, \mathrm{NH}_{4}^{+}, \mathrm{Na}+, \mathrm{SO}_{4}^{2-}$, $\mathrm{NO}_{3}^{-}, \mathrm{Cl}^{-}, \mathrm{Br}^{-}$, and $\mathrm{H}_{2} \mathrm{O}$, J. Geophys. Res.-Atmos., 107, 4207, https://doi.org/10.1029/2001jd000451, 2002.

Wildt, J., Mentel, T. F., Kiendler-Scharr, A., Hoffmann, T., Andres, S., Ehn, M., Kleist, E., Müsgen, P., Rohrer, F., Rudich, Y., Springer, M., Tillmann, R., and Wahner, A.: Suppression of new particle formation from monoterpene oxidation by $\mathrm{NO}_{\mathrm{x}}$, Atmos. Chem. Phys., 14, 2789-2804, https://doi.org/10.5194/acp14-2789-2014, 2014.

Worton, D. R., Goldstein, A. H., Farmer, D. K., Docherty, K. S., Jimenez, J. L., Gilman, J. B., Kuster, W. C., de Gouw, J., Williams, B. J., Kreisberg, N. M., Hering, S. V., Bench, G., McKay, M., Kristensen, K., Glasius, M., Surratt, J. D., and Seinfeld, J. H.: Origins and composition of fine atmospheric carbonaceous aerosol in the Sierra Nevada Mountains, California, Atmos. Chem. Phys., 11, 10219-10241, https://doi.org/10.5194/acp-11-10219-2011, 2011.

Wu, Z. J., Poulain, L., Henning, S., Dieckmann, K., Birmili, W., Merkel, M., van Pinxteren, D., Spindler, G., Müller, K., Stratmann, F., Herrmann, H., and Wiedensohler, A.: Relating particle hygroscopicity and $\mathrm{CCN}$ activity to chemical composition during the HCCT-2010 field campaign, Atmos. Chem. Phys., 13, 79837996, https://doi.org/10.5194/acp-13-7983-2013, 2013.

Xu, L., Guo, H. Y., Boyd, C. M., Klein, M., Bougiatioti, A., Cerully, K. M., Hite, J. R., Isaacman-VanWertz, G., Kreisberg, N. M., Knote, C., Olson, K., Koss, A., Goldstein, A. H., Hering, S. V., de Gouw, J., Baumann, K., Lee, S. H., Nenes, A., Weber, R. J., and Ng, N. L.: Effects of anthropogenic emissions on aerosol formation from isoprene and monoterpenes in the southeastern United States, P. Natl. Acad. Sci. USA, 112, 37-42, https://doi.org/10.1073/pnas.1417609112, 2015a.

$\mathrm{Xu}$, L., Suresh, S., Guo, H., Weber, R. J., and Ng, N. L.: Aerosol characterization over the southeastern United States using high-resolution aerosol mass spectrometry: spatial and seasonal variation of aerosol composition and sources with a focus on organic nitrates, Atmos. Chem. Phys., 15, 7307-7336, https://doi.org/10.5194/acp-15-7307-2015, 2015b.

Ye, P. L., Ding, X., Hakala, J., Hofbauer, V., Robinson, E. S., and Donahue, N. M.: Vapor wall loss of semi-volatile organic com- pounds in a Teflon chamber, Aerosol Sci. Technol., 50, 822-834, https://doi.org/10.1080/02786826.2016.1195905, 2016.

Yeung, M. C., Lee, B. P., Li, Y. J., and Chan, C. K.: Simultaneous HTDMA and HR-ToF-AMS measurements at the HKUST Supersite in Hong Kong in 2011, J. Geophys. Res.-Atmos., 119, 9864-9883, https://doi.org/10.1002/2013jd021146, 2014.

Zhang, J. Y., Hartz, K. E. H., Pandis, S. N., and Donahue, N. M.: Secondary organic aerosol formation from limonene ozonolysis: Homogeneous and heterogeneous influences as a function of NOx, J. Phys. Chem. A, 110, 11053-11063, https://doi.org/10.1021/jp062836f, 2006.

Zhang, Q., Jimenez, J. L., Canagaratna, M. R., Ulbrich, I. M., Ng, N. L., Worsnop, D. R., and Sun, Y. L.: Understanding atmospheric organic aerosols via factor analysis of aerosol mass spectrometry: a review, Anal. Bioanal. Chem., 401, 3045-3067, https://doi.org/10.1007/s00216-011-5355-y, 2011.

Zhang, R. Y., Khalizov, A., Wang, L., Hu, M., and Xu, W.: Nucleation and Growth of Nanoparticles in the Atmosphere, Chem. Rev., 112, 1957-2011, https://doi.org/10.1021/cr2001756, 2012.

Zhang, S. H., Shaw, M., Seinfeld, J. H., and Flagan, R. C.: Photochemical aerosol formation from alpha-pinene- and beta-pinene, J. Geophys. Res.-Atmos., 97, 20717-20729, 1992.

Zhang, X., Cappa, C. D., Jathar, S. H., McVay, R. C., Ensberg, J. J., Kleeman, M. J., and Seinfeld, J. H.: Influence of vapor wall loss in laboratory chambers on yields of secondary organic aerosol, P. Natl. Acad. Sci. USA, 111, 5802-5807, https://doi.org/10.1073/pnas.1404727111, 2014.

Zhang, X., Schwantes, R. H., McVay, R. C., Lignell, H., Coggon, M. M., Flagan, R. C., and Seinfeld, J. H.: Vapor wall deposition in Teflon chambers, Atmos. Chem. Phys., 15, 4197-4214, https://doi.org/10.5194/acp-15-4197-2015, 2015.

Zhao, D. F., Buchholz, A., Kortner, B., Schlag, P., Rubach, F., Kiendler-Scharr, A., Tillmann, R., Wahner, A., Flores, J. M., Rudich, Y., Watne, ̊. K., Hallquist, M., Wildt, J., and Mentel, T. F.: Size-dependent hygroscopicity parameter $(\kappa)$ and chemical composition of secondary organic cloud condensation nuclei, Geophys. Res. Lett., 42, 10920-10928, https://doi.org/10.1002/2015gl066497, 2015a.

Zhao, D. F., Kaminski, M., Schlag, P., Fuchs, H., Acir, I.-H., Bohn, B., Häseler, R., Kiendler-Scharr, A., Rohrer, F., Tillmann, R., Wang, M. J., Wegener, R., Wildt, J., Wahner, A., and Mentel, Th. F.: Secondary organic aerosol formation from hydroxyl radical oxidation and ozonolysis of monoterpenes, Atmos. Chem. Phys., 15, 991-1012, https://doi.org/10.5194/acp-15-991-2015, 2015 b.

Zhao, D. F., Buchholz, A., Kortner, B., Schlag, P., Rubach, F., Fuchs, H., Kiendler-Scharr, A., Tillmann, R., Wahner, A., Watne, ̊. K., Hallquist, M., Flores, J. M., Rudich, Y., Kristensen, K., Hansen, A. M. K., Glasius, M., Kourtchev, I., Kalberer, M., and Mentel, Th. F.: Cloud condensation nuclei activity, droplet growth kinetics, and hygroscopicity of biogenic and anthropogenic secondary organic aerosol (SOA), Atmos. Chem. Phys., 16, 1105-1121, https://doi.org/10.5194/acp16-1105-2016, 2016.

Ziemann, P. J. and Atkinson, R.: Kinetics, products, and mechanisms of secondary organic aerosol formation, Chem. Soc. Rev., 41, 6582-6605, https://doi.org/10.1039/c2cs35122f, 2012. 